\title{
Review
}

\section{Toxicological Issues of Nanoparticles Employed in Photocatalysis}

\author{
Stefanie Wagner, ${ }^{1, *}$ Jonathan Bloh, ${ }^{1}$ \\ Cornelia Kasper ${ }^{1}$ and Detlef Bahnemann ${ }^{1}$ \\ ${ }^{1}$ Institut für Technische Chemie, Leibniz Universität \\ Hannover
}

\begin{abstract}
A huge amount of different nanomaterials is nowadays on the market used for various specific applications. Some nanomaterials such as $\mathrm{TiO}_{2}, \mathrm{ZnO}$ as well as several other semiconductors exhibit photocatalytic activity.

Hence these materials are used for many applications, e.g., for self-cleaning and antibacterial coatings on different surfaces and for the purification of wastewater where the cleaning can be induced by simple exposure to sunlight. Because of the frequent use of these nanoparticles it is important to investigate the life cycles of these nanostructured materials as well as their environmental impact and their toxicity to animals and humans.

This review first gives a short overview about nanotechnology and nanotechnological products as well as about photocatalysis and semiconductors used in this field. We then discuss the need for a new technology named nanotoxicology and the problems occurring when investigating the toxic potential of nanomaterials as well as the life cycle of nanomaterials. Furthermore, we focus on the environmental impact of $\mathrm{TiO}_{2}$ and $\mathrm{ZnO}$ nanoparticles including toxic effects to bacteria, water organisms and plants as well as their toxic effects to humans including in vitro and in vivo studies.
\end{abstract}

Keywords. Nanotoxicology, nanotechnology, $\mathrm{TiO}_{2} \mathrm{ZnO}$, photocatalysis, environmental impacts, human health risks, in vivo studies, in vitro studies.

PACS $^{\circledR}($ 2010). 87.85.Rs, 79.63.Bd, 78.67.Bf.

\section{Nanotechnology}

The technological progress allows the production of new tiny materials which have the size of only a few nanometers. Nanotechnology deals with the production, investigation and utilization of these extremely small particles [1].

\section{Corresponding author:}

Stefanie Wagner, E-mail: wagner@iftc.uni-hannover.de.

Received: November 30, 2010. Accepted: February 08, 2011.
Nanotechnology is projected to become one of the key technologies of the $21^{\text {th }}$ century [2]. In the nanometer range several physical and chemical properties of materials change which can be specifically used for many applications.

Nanoparticles have an extremely high surface to volume ratio and new effects, properties and functions can be observed in the nanometer scale [3]. Mechanical, optical, magnetic, electrical and chemical properties are not only depending on the material but also on the size and shape of the particles. New phenomena occur which cannot be explained by the laws of classical physics, e.g., quantum effects start playing a role as the particles get very small.

The fabrication of nanomaterials can be achieved employing the top-down or the bottom-up method, respectively. With the top-down process nanoscale materials are produced by miniaturization of any type of source material. The nanoparticles can be build up to more complex systems or can be mixed to other materials to modify their properties. Today this approach dominates in physics and physical techniques with the modern semiconductor industry being just one example. However, the constant development of miniaturization in the semiconductor industry is limited and is not able to follow the increase of the number of transistors [4]. Moreover, the top-down approach is an energy extensive, waste producing and resource wasting process.

Using the bottom-up approach nanomaterials are assembled from atoms or molecules. This approach is frequently used in chemistry and biology. The nanoparticles and their assemblies are, for example, synthesized by chemical vapor deposition or by crystal growth from suitable seeds. One promising approach is the growth by self-assembly [5], [6]. Typical materials synthesized employing the bottomup process are carbon nanotubes and nanocrystalline zeolites. Since the bottom-up and the self-assembly process can be used in almost every scale these methods are extremely powerful.

Potential applications of nanomaterials can be found in nearly all sectors of industry. In the information and communication sector nanotechnology is specifically important for the production of processors because of the resulting miniaturization. Furthermore, photonic crystals with their potential application in the area of optical circuitry are of great interest for information processing based only on light (photonics).

Nanostructured materials can also be adopted for medical and health care applications [7], e.g., as biocompatible materials produced for the use as implants and for tissue engineering [8], [9]. Moreover, drugs can be transported in the organism and released on target (drug delivery) [10], 


\begin{tabular}{l|l} 
Industry Sector & Application \\
\hline Chemistry & Paints [21], Catalysts [22], [23], Hydrogen Storage [24] \\
\hline Automotive Industry & $\begin{array}{l}\text { Wheel Fillers, Antireflection Coatings [25], Scratch-Resistant Paints, De-Mister } \\
\text { Coatings, Fuel Cells }\end{array}$ \\
\hline Optical Industry & White LEDs, Quantum Dot Laser, Photonic Crystals, \\
\hline Medicine and Health Care & $\begin{array}{l}\text { Implant Materials [8], [9] Drug Delivery, [10], [11] Functional Foods [26], Cos- } \\
\text { metics, Fluorescent Biological Labels [12], [13], [14], Detection of Pathogens [15] } \\
\text { Proteins [16], Hyperthermia [18], Antibactericidal Surfaces [21] }\end{array}$ \\
\hline Environmental Technology & $\begin{array}{l}\text { Water Treatment [27], Solar Energy [28], Conversion and Storage Systems, Pollution } \\
\text { Control and Abatement }\end{array}$ \\
\hline $\begin{array}{l}\text { Information and Communica- } \\
\text { tion Technology }\end{array}$ & Processors
\end{tabular}

Table 1. Applications of nanoparticles.

[11], and the availability of bioactive substances can be increased (functional foods). Nanoparticles can also be used as fluorescent labels [12], [13], [14], and for the biodetection of pathogens [15] and proteins [16]. Another application of nanotechnology is the separation and purification of biological molecules and cells [17]. A promising and important use in medicine is the selective tumor destruction with nanomaterials via heating called hyperthermia [18].

In the automotive industry nanotechnological products are used as wheel fillers, antireflection coatings, scratchresistant paints and hydrophilic coatings as de-mister surfaces. Nanoscale materials are used in photovoltaic devices and fuel cell for power supplies. The application of nanotubes in lithium-ion-accumulators can increase the capacity of batteries and mini-accumulators. In the construction industry the application of nanoscale materials in metals enables an essential contribution to light construction. The admixing of silica nanoparticles to construction materials enhances some material properties such as adhesive pull strength and adhesive shear strength between concrete and armoring steel. In environmental technology nanoparticles are used as catalysts for water treatment and for the elimination of pollutants. The underlying mechanism and the employed materials for this purpose will be discussed in more detail in the following section (photocatalysis). It is obvious that nanotechnology products have a wide range of different applications and have already entered their commercial exploration period [19], [20].

Nanostructured materials already exist much longer than the rather recent emergence of nanotechnology. Many longexisting materials are in fact structured on the micro- and nanometer scale and many industrial processes that have been used for decades such as polymer and steel manufacturing exploit nanoscale phenomena. Natural processes have produced nanoparticles for eons for example volcanic eruptions. Nanometer-sized particles are created in countless physical processes like erosion and combustion and the natural world is full of examples of systems with nanoscale structures, e.g., proteins, cells, bacteria, viruses, etc.

Because nanomaterials are used in many different applications and are generated as by-products in technical processes it is important to investigate their potential environmental risks as well as the possible hazards to animals and human beings.

\section{Photocatalysis and Photocatalysts}

The fundamental principle of semiconductor photocatalysis is the ability of the employed catalyst particles to absorb photons to create reactive electron-hole-pairs which are capable of oxidizing most organic and inorganic compounds. This phenomenon is the basis for a variety of current and projected applications in different fields, such as surface technology, pollution management and medicine.

Briefly, when a semiconducting material absorbs a photon with an energy equal or higher than its bandgap energy, an electron is excited from the valence to the conduction band. Simultaneously, a positively charged hole $\left(\mathrm{h}^{+}\right)$is created in the valence band [29]. Recombination of these two charge carriers will result in the generation of heat or in the reemission of a photon. However, once these two charge carriers reach the surface of the semiconductor, they can undergo a variety of reactions with surfaceadsorbed molecules (see Figure 1). For many applications, the most relevant reaction is the oxidation reaction, as the photogenerated hole in the valence band of, i.e., the very frequently used photocatalyst titanium dioxide $\left(\mathrm{TiO}_{2}\right)$, has a sufficiently high redox potential to be able to oxidize most organic compounds. In addition to the direct reaction with the holes, this oxidation reaction can be mediated by several active oxygen species. These mediators include but are not limited to hydroxyl radicals $\left({ }^{\bullet} \mathrm{OH}\right)$, superoxide radicals $\left(\mathrm{O}_{2}^{\bullet-}\right)$, and singlet oxygen $\left({ }^{1} \mathrm{O}_{2}\right)$ [30], [31], [23], [32], [33]. 


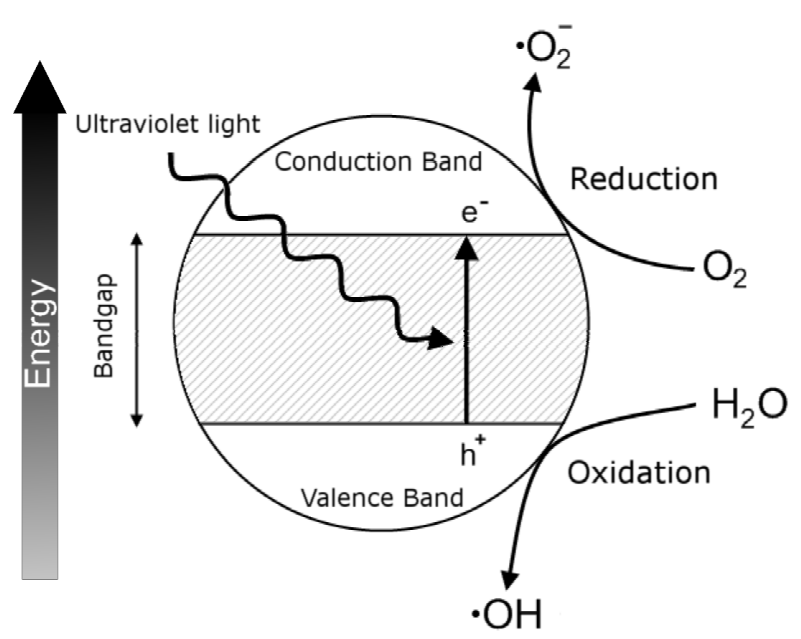

Figure 1. Illustration of the fundamental principle of photocatalysis.

Similarly, the conduction band electron can react with adsorbed molecular oxygen forming superoxide radicals and subsequently hydrogen peroxide $\left(\mathrm{H}_{2} \mathrm{O}_{2}\right)$ However, the oxidizing potential of photocatalytic materials is not limited to their surface, as oxidizing species can diffuse away from the photocatalytic surface, inducing redox reactions in the bulk. This effect is usually called remote photocatalysis and is most likely mediated through hydrogen peroxide and singlet oxygen [34], [35], [36], [37], [38], [39], [40], [41], [42], [43], [44], [45] [46], [27]. However, in the case of remote photocatalysis, the reaction rate and thus the product yield is usually one or two orders of magnitude lower than that of the process occurring at the photocatalyst surface. In many cases, only the initial oxidation reaction is photocatalytic, forming a reactive radical that is further oxidized by molecular oxygen, eventually resulting in the formation of carbon dioxide [47]. Besides this exergonic reaction sequence, photocatalytic fuel synthesis, e.g., the cyclic splitting of water into molecular hydrogen and oxygen, presents another very interesting application of photocatalysis that currently receives increased attention and has been the topic of several recently published reviews [48], [49], [50].

Given that photocatalysis is a surface phenomenon, a high surface area potentially contributes to a high photocatalytic activity. Additionally, if the particles are small enough, their light scattering properties become negligible and suspensions or coatings made from these particles will appear optically transparent, which is an important property for many applications [51]. For these reasons, preferably materials exhibiting a high specific surface area and minute dimensions are used in applications, specifically nanoparticles and nanostructured materials [52].

Although sometimes non-oxidic compounds ( $\mathrm{CdSe}$, $\mathrm{ZnS}, \mathrm{GaP}$ ) are used as photocatalysts, their instability in aqueous environments and their susceptibility to photo- corrosion greatly limits their applications [53], [27], [54]. Therefore, most applications employ the more stable metal oxide semiconductors such as $\mathrm{TiO}_{2}, \mathrm{ZnO}$, and in some cases, $\mathrm{Fe}_{2} \mathrm{O}_{3}$ and $\mathrm{WO}_{3}$ as photocatalysts. Unfortunately, due to their rather high bandgap energy of $3.2 \mathrm{eV}$, the use of $\mathrm{TiO}_{2}$ and $\mathrm{ZnO}$ is limited to light in the ultraviolet region, i.e., below $400 \mathrm{~nm}$. Ultraviolet light, however, only constitutes a small portion of the sunlight. For this reason, the catalysts are sometimes modified by doping, e.g., incorporating $\mathrm{N}, \mathrm{C}$, and or $\mathrm{S}$ atoms into the bulk material or by surface modification, e.g., depositing noble metal islands as electron transfer catalysts in order to achieve better photocatalytic activity and/or an activity under visible light irradiation.

So far photocatalysis has been proposed for or applied in a variety of applications. Currently, the two most important application fields are surface technology and waste management. In surface technology, surfaces are coated with photocatalytic material to achieve several different properties. One of these properties is the so-called self-cleaning effect: organic pollutants are photocatalytically degraded on surfaces coated with photocatalysts as long as they are illuminated with a sufficient amount of ultraviolet light. This technique is applied to glass surfaces, outdoor building façades, roof tiles, ceramics, plastics and even fabrics and wool [55], [56], [57], [25], [58]. Since the surface can not only be cleaned from organic pollutants but can also be disinfected, the photocatalytic technology can also be used for medical instruments or for surfaces in medical facilities [59], [60], [61].

Another important application of photocatalytic surfaces is the decontamination, deodorization and disinfection of indoor air. Interior facilities are often contaminated with malodorous compounds that reduce the living quality of the residents. Additionally, construction materials and furniture often emit volatile organic compounds (VOCs) in low concentrations. These VOCs may be harmful for the inhabitants and cause diseases such as the sick building syndrome. Since almost all airborne pollutants can be degraded by photocatalysis, using this technique to clean the air is more reliable and needs less maintenance than conventional filterbased air-purification systems. Furthermore, since bacteria, fungal spores and viruses are also degraded in this process, they can help to reduce the number of infections transmitted in hospitals and other medical facilities.

Likewise, this method can also be applied for outdoor air purification. The main aim here is, however, to reduce environmental pollutants such as nitrous oxides. Construction materials, roads and pavements are thus modified with photocatalytic material in an attempt to reduce pollutant levels in high-traffic regions [62], [63], [64], [65], [66].

Photocatalysis can also play an important role in industrial and communal waste water management. The advantage of using photocatalysis for waste water treatment is that, unlike in other advanced oxidation techniques, besides 
air no external reagent (e.g., $\mathrm{O}_{3}, \mathrm{H}_{2} \mathrm{O}_{2}$ ) is needed for the reaction. This makes photocatalysis a potentially cheaper and easier to operate alternative to conventional advanced oxidation techniques for the decontamination of waste water [27], [67], [68], [69], [70], [71]. However, besides the engineering of appropriate reactors the main current drawback for a wider application of this technology for water treatment is the lack of photocatalysts exhibiting sufficient and long-lasting activity and/or being able to utilize also visible light.

\section{Nanotoxicology}

Currently, a wide range of nanoparticles of different types and exhibiting different properties are being synthesized which are going to be tested for their suitability for various industrial applications. As more and more technological products are becoming available to the customers, concerns have been raised regarding the harmlessness and the potential toxicity of these materials [72], [73], [74]. Every technology or designed product requires careful investigations regarding its sustainability and the associated risk potential before being introduced into the market. For this reason, a new subdiscipline of nanotechnology namely nanotoxicology emerged [75], [76]. Nanotoxicology was initially defined as the science dealing with the effect of engineered nanomaterials and nanostructures on living organisms emerging from the toxicology of ultrafine airborne particles [75]. If the definition of toxicology is adapted to nanomaterials, nanotoxicology can be described as the science dealing with the environmental impact and the hazard of nanomaterials for living organisms as well as the interaction of these materials with biological and environmental systems, including the prevention and minimization of adverse effects caused by nanomaterials [74].

Various new difficulties and subsequent new approaches result from the investigation of the toxicity of nanostructured materials, because compared to their bulk counterparts nanomaterials exhibit a different behavior resulting from property changes in the nanoscale regime.

One of the important factors in nanotoxicology is the possible exposure to nanoparticles and the life cycle of nanostructured materials. The main problem in the determination of the exposure is the lack of labeling of products containing nanomaterials and the lack of knowledge of the concentration of these materials in the environment. Appropriate measurements of particle concentrations and doses and the knowledge of produced materials and their disposal in the environment therefore constitute the first perrequisite for this new discipline. Natural airborne particles in the environment add to the extremely complicated task of the determination of anthropogenic nanoparticles. There are some approaches to determine, to calculate and, or to measure the number of particles in a given environment [77], [78], [79],
[80], [81]. Furthermore, since workers and consumers have to be protected, a labeling of nanomaterials will be needed.

Toxicity testings of nanomaterials in vivo or in vitro by establishing dose-response relationships have been developed to identify a potential hazard. Because risk is a function of hazard and exposure [risk $=f$ (hazard, exposure)], the approach is to incorporate both components into a paradigm. Therefore, hazard identification has to be achieved and consequently dose-response and exposure assessment must be carried out. Following these steps the risk assessment and finally the risk management can executed [83], [84].

The characterization of nanomaterials is very important and several nanoparticle classes have to be identified. The physiochemical characteristics and the biological reactivity of particles play important roles. The chemical structure alone is not sufficient to characterize nanomaterials, but rather shape, size (ferret/hydrodynamic), size distribution, agglomeration/aggregation, stability, solubility in different media, surface properties (area/porosity, charge, reactivity, coatings/contaminants, defects), composition and crystal structure have to be determined to enable a judgment concerning the possible hazards of these materials. These properties can change with the method of production, the preparation process, the storage of materials and the introduction into physiological media and the organism. It is not possible to compare the toxicity of nanomaterials to that of their bulk counterparts, because as described in Section 1 the reactivity and the material properties are not identical. Size is an important parameter to predict entry routes, efficiency and translocation of nanoparticles in the organism. Their surface charge may contribute to possible molecular interactions.

Due to their small size, the particles can usually be easily incorporated into the human body. The most important and most investigated adsorption pathway is the assimilation via the lung. Several studies highlight the possible hazard of lung diseases caused by nanomaterials reaching the respiratory tract [85], [86], [87], [88]. Exposition and inhalation studies show the incorporation of particles in the lung and the localization and possible elimination of particles depending on their size, shape, aggregation and surface area [89], [90], [91], [92]. A considerable amount of research demonstrates the toxicity of combustion-derived particles such as diesel soot [90], [91], welding fume [92], carbon black [93], and coal fly-ash [94]. However, there are also studies concerning the incorporation of nanoparticles via the skin [95]. Until now, there is no evidence that the nanoparticles can enter the organism via skin adsorption. Usually the particles are located in the horny layers while only a very small fraction of nanoparticles such as $\mathrm{TiO}_{2}$ and $\mathrm{ZnO}$ used in sunscreens was found to penetrate into deeper tissue layers but only inside single follicle channels. [96], [97], [98], [99]. Luke et al., however, showed that Quantum Dots are able to penetrate the skin [100]. 


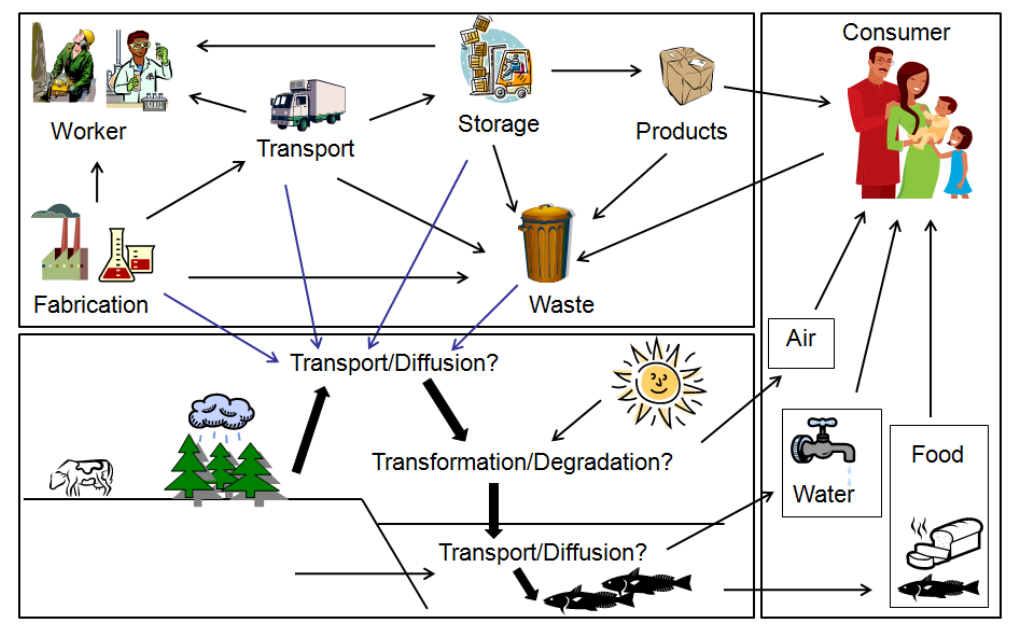

Figure 2. : Scheme of the life cycle of nanomaterials [82].

Besides these "natural" or accidental adsorption pathways of nanoparticles into the organism, intended insertion of nanoparticles into the body occurs for medical applications either intravenously [101] or when present as a layer on bone tissue implants [8], [9].

After entering the organism, nanoparticles will most likely be able to move freely because of their small size thus reaching almost every part of the body. Various studies have shown that the localization of particles in the body depends on their adsorption path in the organism [102] as well as on their size and shape [103]. The effective clearance mechanism of particles that had entered the tissues was also found to depend on their size [104], [105]. Translocation and toxicity are also regulated by specific cellular interactions and by specific nanomaterial factors, such as their biochemical stability and their potential to generate reactive oxygen species (ROS) [106]. ROS can cause oxidative stress which has been linked to increased cytotoxicity [107], [108], [109], [110].

Nanoparticles can interact with various biological molecules such as proteins [111], [112] and are able to penetrate the cell membrane interacting with DNA and causing DNA damage [113]. Evidence has also been presented that nanoparticles can break through the blood-brain-barrier [95], [114]. The surface charge will influence nonspecific adhesion of proteins on the nanomaterials surface as well as its permeation through junctions and its cellular uptake [104].

As mentioned before, particles can react with proteins. Therefore, the particle size, the aggregation and the agglomeration state in the biological media used for cell culture tests has to be determined. It is important to verify that during any test nanoparticles and not only aggregates of particles are still in the culture media [115].

Several studies show that particles exhibit a different behavior in the culture medium as compared to aqueous sus- pensions. Some particles are stabilized by the proteins in the cell culture media while some are aggregated by salts [116], [117], [118], [119], [120].

This overview concerning nanotoxicology research illustrates the difficulties in applying generalized concepts for the prediction of nanomaterial permeation, of cellular uptake and of toxicity in biological systems. Nanotoxicology is an emerging field with a lot of antagonisms existing in the published literature since standardized tests do currently not exist.

\section{Environmental Impacts of Nanoparticles}

The environmental impact caused by nanomaterials is presently being extensively discussed in particular in correlation with the regulations concerning airborne particulate matter. To be able to estimate the potential risk of nanomaterials informations concerning their mobility and the life cycle are of crucial importance.

Furthermore, a clear differentiation between particles generated by technical processes and those unintended released is definitely required. Most of the latter particles are generated by combustion processes (flow ash, diesel soot, catalyst dust, carbon black).

Naturally occurring nanoparticles vary in size, composition and shape, whereas artificial nanomaterials are more uniform because they are synthesized for special applications. With the progressive development of traffic a drastic increase of ultrafine particles in the air is noticeable. The life cycle of nanomaterials is not obvious, cf. Section 3. Depending on production and use, nanomaterials can be emitted into air or water and can thus be found on the ground or in ground or surface water, respectively.

Investigations of combustion-derived ultrafine particles can assess the behavior and the impact of nanoparticles 
in the environment. The ultrafine particles produced by diesel engines have the property to agglomerate and to subsequently sediment within a few days, hence, these dusts are eliminated from the air after a certain period of time. Synthesized, artificial particles frequently do not agglomerate because they are often stabilized with, e.g., core-shellsystems for specific applications; consequently, they stay in the air for a longer period of time and can travel over long distances.

Because of their large surface area nanoparticles can adsorb more pollutants and bigger amounts of toxic substances such as pesticides, fertilizer, pollutants and heavy metals, which can thus be transported over long distances and can be widely distributed [121]. Due to their high reactivity nanoparticles may react with natural substances possibly forming toxic compounds or composites. Furthermore, the bactericidal effect of some materials could change the microbial composition in the water or on the ground. To assess the environmental hazard, most studies investigate the impact and toxic effects of nanomaterials to organisms living in water. The first step in an investigation of this exposure route is the characterization of the form and the concentration of engineered nanomaterials in water since this is where many substances exhibit their most significant environmental impact. Materials present in water can be degraded, transformed and/or accumulated in a variety of ways.

In the following we will focus on the environmental effects caused by semiconductors such as $\mathrm{TiO}_{2}$ and $\mathrm{ZnO}$ used in photocatalysis. The life cycle of these materials is long. They can be released to the environment from laboratories and factories during their production processes. Because of the wide use as photocatalysts release to the environment is also possible from products containing these materials, such as photocatalytic wall paints and coated surfaces, e.g., roof tiles. In some products the photocatalyst particles are present in solutions, e.g., during the treatment of wastewater. In others they are present as fixed particles in coatings. $\mathrm{TiO}_{2}$ and $\mathrm{ZnO}$ nanoparticles are being prepared in large quantities and in many different varieties; some are even stabilized with proteins and other reagents. As mentioned before, the bactericidal effect of materials can also have an environmental impact.

\section{Bactericidal Effect of $\mathrm{TiO}_{2}$ and $\mathrm{ZnO}$ Nanoparticles}

The toxic effect of illuminated $\mathrm{TiO}_{2}$ and $\mathrm{ZnO}$ nanoparticles is being thoroughly investigated and many papers have been published on this topic with the majority of these studies being performed with $\mathrm{TiO}_{2}$ because this is by far the most used photocatalyst.

When exposed to near-UV light, titanium dioxide exhibits a strong bactericidal activity. However, the underlying killing mechanism of this photocatalytic reaction is not yet well understood. Recently, total oxidation of Esche- richia coli cells has been demonstrated [122]. The reactive oxygen species (ROS) generated by the $\mathrm{TiO}_{2}$ photocatalytic reactions cause various damages to living organisms. This is not surprising since the latter are composed of organic compounds. In 1985, Matsunaga and coworkers reported the microbiocidal effect of $\mathrm{TiO}_{2}$ photocatalytic reactions for the first time [123].

E. coli has been chosen in many studies to investigate the toxic effect of photocatalysis [124], [125], [126]. Coleman et al. examined the photocatalytic degradation of E. coli in water comparing various catalysts and showed that $\mathrm{TiO}_{2}$ (P25) was the most efficient catalyst. Non-buffered water samples displayed a greater bactericidal efficiency, which was attributed to a decrease in the electrostatic repulsion between $\mathrm{TiO}_{2}$ and $E$. coli and to elevated stress on E. coli at acidic pH. Buffered samples showed a decrease in bactericidal efficiency which was attributed to the presence of $\mathrm{HCO}_{3}^{-}$-ions competing for oxidizing species and blocking the surface of the $\mathrm{TiO}_{2}$-particles [124].

It has also been shown that $\mathrm{TiO}_{2}$ photocatalyst particles illuminated with UV-light exhibit high disinfection rates against other microorganisms besides E. coli such as Lactobacillus acidophilus and Saccharomyces cerevisiae [123], Lactobacillus helveticus [127], Pseudomonas aeruginosa [128] Pseudomonas stutzeri [129] and Bacillus pumilus [130].

The toxic effect of photocatalytic systems to bacteria such as Pseudomonas aeruginosa, Staphylococcus aureus, Enterococcus faecium and Candida albicans which are relevant for hygiene has also been investigated [131]. Kuhn et al. observed a high mortality for all these bacteria on UVilluminated surfaces coated with $\mathrm{TiO}_{2}$ (P25) and proposed that ${ }^{\bullet} \mathrm{OH}$-radicals formed on the catalyst surface are causing this effects [131].

Gogniat et al. analyzed the bactericidal effect of UVilluminated $\mathrm{TiO}_{2}$ in $\mathrm{NaCl}-\mathrm{KCl}$ or sodium phosphate solutions to an E. coli strain. They found that the adsorption of bacteria on the catalyst occurred immediately in $\mathrm{NaCl}-\mathrm{KCl}$ solution, whereas it was delayed in the sodium phosphate solution. Moreover, the adsorption rate of the cells onto the catalyst was found to be positively correlated with its bactericidal effect. The authors suggest that the photocatalytic bactericidal effect is related to the loss of membrane integrity of the cells aggregated on the $\mathrm{TiO}_{2}$ surface [132].

The toxic effect of $\mathrm{TiO}_{2}$ photocatalysis to phytophatogenic bacteria is not only a chance to alternatively control plant diseases rather than using pesticides, but it can also present a hazard which currently cannot yet be estimated [133], [134].

The photocatalytic activity of $\mathrm{ZnO}$ nanoparticles on different microorganisms has also been reported [135], [136], [137], [138]. Upon UV(A)-illumination $\mathrm{ZnO}$ causes a significant growth inhibition to E. coli [136], [137], [138], Bacillus subtilis [139], Streptococcus agalactiae, and Staphylococcus aureus, with the latter two being patho- 
genetic agents causing several infective diseases [135]. The antibactericidal activity of $\mathrm{ZnO}$ to Staphylococcus epidermidis, Streptococcus pyogenes, Enterococcus faecalis [139] has also been investigated. Jones et al. found the antibacterial activity of $\mathrm{ZnO}$ nanoparticles to depend on their size, with smaller particles exhibiting a greater efficacy for the bacteria growth inhibition.

While in the absence of $\mathrm{UV}$ illumination $\mathrm{TiO}_{2}$ is not able to inhibit the growth of, e.g., Staphylococcus aureus significantly, $\mathrm{ZnO}$ particles are found to also exhibit bactericidal activity in the dark [140], [141].

Brayner et al. observed that synthesized $\mathrm{ZnO}$ nanoparticles with average particle diameters of $12 \mathrm{~nm}$ are able to inhibit the bacterial growth ( $100 \%$ at concentrations of $3 \mathrm{mM}$ ) and suggested this to be due to the disorganization of the E. coli membranes. As a consequence the membrane permeability increases leading to the accumulation of nanoparticles in the bacterial membrane and the cytoplasm of the cells [142].

Roselli et al. proposed that the toxic effect of $\mathrm{ZnO}$ to E. coli is related to zinc ions which are metabolized as an oligo-element [138]. Certain bacteria have developed mechanisms to regulate the influx and efflux processes to maintain a steady intracellular concentration of metal ions, including the $\mathrm{Zn}^{2+}$ ion. The genes responsible for the transport of zinc ions have also been characterized in several bacteria, including Streptococcus pneumoniae, Haemophilus influenzae, Staphylococcus aureus, E. coli, and Bacillus subtilis [143], [144].

\section{Impacts of $\mathrm{TiO}_{2}$ and $\mathrm{ZnO}$ Nanoparticles on Water Organisms and Plants}

The effect of nanoparticles on water organisms and plants also plays an important role concerning the environmental impact of nanotechnological products, because nanoparticles may be released into freshwater systems as a result of their use for the treatment of waste from industry and medicine. There are only a few studies investigating these interactions. Free radicals generated by the irradiation of photocatalysts may cause a risk for organisms living in water.

Hundt-Rinke et al. investigated the effect of two different nanoparticle suspensions under appropriate illumination to induce their photocatalytic activity. The growth inhibition of the green alga Desmodesmus subspicatus and the immobilization of Daphnia magna were selected as test reaction, respectively. It was shown that nanoparticles may induce ecotoxicological effects depending upon the nature of these particles. $\mathrm{TiO}_{2}$ particles with a size of $25 \mathrm{~nm}$ mainly consisting of anatase exhibited a harmful effect on algae $\left(\mathrm{EC}_{50^{-}}\right.$ values $44 \mathrm{mg} / \mathrm{L}$ ), whereas pure anatase with a size of 100 $\mathrm{nm}$ show no toxic effect to the algae (maximum investigated concentration $50 \mathrm{mg} / \mathrm{L}$ ). In the tests performed with daphnia, toxicity was observed for both $\mathrm{TiO}_{2}$ nanoparticles
[145]. Lovern and coworkers also investigated the toxic effect of $\mathrm{TiO}_{2}$ to daphnia and reported an increase in mortality with an increase of the nanoparticle concentration [146].

Velzeboer et al. investigated the ecotoxic effect of some nanomaterials employing different methods and ecotoxicity endpoints. Four different ecotoxicity tests were performed: the Microtox ${ }^{\circledR}$ test, the pulse-amplitude modulation (PAM) test, the Chydotox test, and the Biolog ${ }^{\circledR}$ test [147]. The Microtox ${ }^{\circledR}$ test uses bioluminescent bacteria, specifically, the strain Vibrio fischeri [148], the pulse-amplitude modulation (PAM) uses the green alga Pseudokirchneriella subcapitata [149], the Chydotox is based on the survival of Chydorus sphaericus, a small, benthic cladoceran [150], and the Biolog ${ }^{\circledR}$ test uses a mix of soil bacteria to determine toxicity via multivariate analysis [151]. No appreciable effects were observed at concentrations up to $100 \mathrm{mg} / \mathrm{L}$ for tested particles $\left(\mathrm{TiO}_{2}, \mathrm{ZrO}_{2}, \mathrm{Al}_{2} \mathrm{O}_{3}, \mathrm{CeO}_{2}\right.$, fullerene $\left(\mathrm{C}_{60}\right)$, singlewalled carbon nanotubes, and polymethylmethacrylate). It was suggested that colloid (in)stability is of primary importance in explaining ecotoxic effects of nanoparticles in the natural environment [147].

The toxicity of $\mathrm{TiO}_{2}$ nanoparticles to the alga Pseudokirchneriella subcapitata was also investigated with bulk $\mathrm{TiO}_{2}\left(\mathrm{EC}_{50}=35.9 \mathrm{mg} / \mathrm{L} / \mathrm{NOAEC}=10,1 \mathrm{mg} / \mathrm{L}\right)$ showing a lower toxicity as compared to their nano formulations $\left(\mathrm{EC}_{50}=5.83 \mathrm{mg} / \mathrm{L} / \mathrm{NOAEC}=0,98 \mathrm{mg} / \mathrm{L}\right)$. Nano $\mathrm{TiO}_{2}$ formed characteristic aggregates entrapping algal cells which may contribute to the toxic effect of nanostructured $\mathrm{TiO}_{2}$ to algae [152].

On the other hand, suspensions of nano and bulk $\mathrm{TiO}_{2}$ were found to be non toxic even at loadings at $20 \mathrm{~g} / \mathrm{L}$ to bacteria Vibrio fischeri and to crustaceans Daphnia magna, and to Thamnocephalus platyurus [153].This study did not include any measurements of the $\mathrm{TiO}_{2}$ particle size in water. Commercially available $\mathrm{TiO}_{2}$ nanoparticles e.g., EvonikDegussa Aeroxide P25 showed no measurable effect on the growth rates of four different phytoplankton species: Thalassiosira pseudonana, Skeletonema marinoi, Dunaliella tertiolecta, and Isochrysis galbana, up to concentrations of $1000 \mu \mathrm{g} / \mathrm{L}$ (ppb) [154].

Zinc oxides were found to be equally toxic to the alga Pseudokirchneriella subcapitata in their bulk and in their nano formulations [151]. The toxicity of $\mathrm{ZnO}$ was attributed to soluble zinc ions originating from the metal oxide particles. This study by Aruoja et al. again demonstrates that solubility appears to be a key issue governing the toxicity of metal containing nanoparticles, at least for organisms that a priori are not internalizing the particles [152].

Heinlaan and coworkers investigated the toxic effect of nano and bulk $\mathrm{ZnO}$ as well as of $\mathrm{Zn}^{2+}$ ions to bacteria $\mathrm{Vib}$ rio fischeri, to crustaceans Daphnia magna and Thamnocephalus platyurus [153]. All Zn formulations were found to be very toxic with the $\mathrm{EC}_{50}$ values determined for Vibrio fischeri being $1,8 \mathrm{mg} / \mathrm{L}$ for bulk $\mathrm{ZnO}, 1,9 \mathrm{mg} / \mathrm{L}$ for 
nano $\mathrm{ZnO}$, and $1,1 \mathrm{mg} / \mathrm{L}$ for $\mathrm{ZnSO}_{4} 7 \mathrm{H}_{2} \mathrm{O}$, for Daphnia magna $8,8 \mathrm{mg} / \mathrm{L}$ for bulk $\mathrm{ZnO}, 3,2 \mathrm{mg} / \mathrm{L}$ for nano $\mathrm{ZnO}$ and $6,1 \mathrm{mg} / \mathrm{L}$ for $\mathrm{ZnSO}_{4} \cdot 7 \mathrm{H}_{2} \mathrm{O}$, and for Thamnocephalus platyurus $0,24 \mathrm{mg} / \mathrm{L}$ for bulk $\mathrm{ZnO}, 0,18 \mathrm{mg} / \mathrm{L}$ for nano $\mathrm{ZnO}$, and $0,98 \mathrm{mg} / \mathrm{L}$ for $\mathrm{ZnSO}_{4} \cdot 7 \mathrm{H}_{2} \mathrm{O}$, respectively. The toxicity was found to be caused by solubilized $\mathrm{Zn}$ ions as proved by tests performed with recombinant $\mathrm{Zn}$-sensor bacteria [153].

Miller et al. showed that $\mathrm{ZnO}$ nanoparticles significantly inhibited the growth rate of four different phytoplankton species: Thalassiosira pseudonana, Skeletonema marinoi, Dunaliella tertiolecta, and Isochrysis galbana. The $\mathrm{ZnO}$ particles aggregated rapidly in seawater forming particles with hydrodynamic diameters exceeding $400 \mathrm{~nm}$ [154]. The toxicity of $\mathrm{ZnO}$ nanoparticles to phytoplankton was likely due to dissolution, release, and uptake of free zinc ions, with specific nanoparticulate effects being difficult to distinguish from effects due to free zinc ions [154], [155].

The toxicity of $\mathrm{Zn}$ and other trace metals to phytoplankton moreover depends on the concentration of other limiting trace metals and nutrients [155]. The mechanism of $\mathrm{Zn}^{2+}$ ion toxicity in phytoplankton can be explained by an antagonism between the toxic metal, in this case zinc, and the nutrient metal. Excessive free $\mathrm{Zn}^{2+}$-ions competitively inhibit manganese uptake, causing Mn deficiency [156]. $\mathrm{Zn}^{2+}$ has also been shown to cause increased ATP production in diatoms, which may be linked to increased thiol and glutathione production [157]. Zn-thiol binding may act as a detoxification mechanism, but the energy required for this reaction may result in a decrease of the cell division rate and therefore of the population growth rate [157].

Mortimer and coworkers investigated the toxic effect of $\mathrm{ZnO}$ nanoparticles on the model organism protozoa Tetrahymena thermophila and reported the $\mathrm{EC}_{50}$ values after $4 \mathrm{~h}$ exposure to be $3,7 \mathrm{mg} / \mathrm{L}$ for bulk $\mathrm{ZnO}, 3,9 \mathrm{mg} / \mathrm{L}$ for nano $\mathrm{ZnO}$, and $4,9 \mathrm{mg} / \mathrm{L}$ for $\mathrm{Zn}^{2+}$, respectively. The toxicity of the zinc compounds was found to be about 1.5 times lower after $24 \mathrm{~h}$ of exposure as compared with an exposure time of $4 \mathrm{~h}$, probably due to adaptation of the organisms [158].

The dissolution of $\mathrm{ZnO}$ nanoparticles and its contribution to the toxicity on ryegrass was also investigated. $\mathrm{Zn}^{2+}$ ions were used to compare and verify the root uptake and phytotoxicity of $\mathrm{ZnO}$ nanoparticles in these hydroponic culture systems. The root uptake and the phytotoxicity were visualized by light, scanning electron, and transmission electron microscopy. In the presence of $\mathrm{ZnO}$ nanoparticles, ryegrass biomass was significantly reduced, root tips were shrunk, and root epidermal and cortical cells highly vacuolated or collapsed. $\mathrm{ZnO}$ nanoparticles were found to be able to concentrate in the rhizosphere, to enter the root cells and to inhibit seedling growth of ryegrass. The phytotoxicity of $\mathrm{ZnO}$ nanoparticles could not primarily be explained by their dissolution in the bulk nutrient solution or in the rhizosphere [159].
Because of the entry of nanotechnological products to the air, the water, and the ground nanoparticles can be adsorbed by plants and mammalian organisms. Hence, they enter the food chain and can cause possible hazards and risks to animals and humans. The toxicological aspects to animals and human beings will be discussed in the following section.

\section{Human health risks of Nanomaterials}

As discussed in Section 4, toxic effects of metal oxide nanomaterials to different bacteria, water organisms and plants have been detected. The potential hazardous effect of semiconductor particles employed in photocatalysis will summarized in this section. Nanoparticles are able to reach the organism via the lung, via the gastrointestinal tract and partly via the skin. Within the organism they can move freely, and should be able to break through the blood-brain barrier and through cell membranes. Via the blood vessels they can reach and eventually accumulate in different organs such as kidney, heart, and liver. In the body nanoparticles are able to interact with different proteins and cell components as described in Section 3. Therefore, various studies have investigated the toxic effect of $\mathrm{TiO}_{2}$ and $\mathrm{ZnO}$ nanoparticles to different cell lines and animals.

Picatonotto et al. investigated the photocatalytic activity of pigments grade titanium dioxide $\left(\mathrm{TiO}_{2}\right)$, used, e.g., in sunscreens and observed a photocatalytic degradation of the organic additives of protective creams and the generation of active species inducing the transformation of biological molecules present on the human skin. Some sunscreens have been photo-degraded after UV-irradiation with the potential risk to act as photosensitizers able to initiate harmful reactions for the skin, especially photo-induced mutagenicity [160]. Hidaka et al. examined the fate of DNA, RNA and their corresponding pyrimidine and purine bases in presence of $\mathrm{TiO}_{2}$ under UV illumination. Although these in vitro studies may not reflect actual in vivo cases it has been demonstrated that illuminated $\mathrm{TiO}_{2}$ interacts with DNA or RNA components with serious damage to these substrates being possible [161]. Lu and coworkers have demonstrated that UV-illuminated pure anatase $\mathrm{TiO}_{2}$ as well as the mixed anatase-rutile Evonik-Degussa Aeroxide P25 can promote the protein tyrosine nitration. The latter is known to occur as a result of oxidative and nitrative stress and is directly involved in the onset or the progression of diseases. On the other hand, the photocatalytic effect of rutile nanoparticles resulting in protein tyrosine nitration was reported to be marginal. Considering the existence of nanostructured $\mathrm{TiO}_{2}$ in the environment and in cosmetics, e.g., sunscreen products along with the high content of nitrite in sweat, UV-exposed skin may be a significant target for the photosensitized damage [162] and for photo-oxidative injuries 
[163], [164], [165]. The potential physiological significance of nano $\mathrm{TiO}_{2}$ induced photocatalytic protein nitration was also demonstrated in mouse skin homogenate. The relationship between photocatalytic protein tyrosine nitration and chronic cutaneous diseases still needs further investigations [162].

\section{In vitro Studies of $\mathrm{TiO}_{2}$ and $\mathrm{ZnO}$ Nanomaterials}

The effect of $\mathrm{TiO}_{2}$ nanoparticles in different sizes, shapes and surface coatings to various cell lines such as $\mathrm{HaCaT}$ cells, an immortalized keratinocyte cell line [166], L929 cells, a mouse fibroblast cell line [167], HeLa cells, an ovarian cell line [168], [169], PC-12 cells, a rat pheochromocytoma cell line [162], [170], [171], A-549, a lung cell line [170], [171], NIH-3T3 cells, a mouse fibroblast cell line [170], [171], and to HEP-G2 cells [170], [171] has been investigated in great detail.

First studies investigating the possible cytotoxic effect of $\mathrm{TiO}_{2}$ nanoparticles to mammalian cells were carried out by Cai and coworkers in 1992 [169]. They observed that HeLa cells showed no more viability after cultivation with photoactivated (10 $\mathrm{min} / 550 \mathrm{~W} \mathrm{Hg}$ lamp) $\mathrm{TiO}_{2}$ nanoparticles (P25) at a loading of $50 \mu \mathrm{g} / \mathrm{ml}$ (50 ppm), whereas the treatment with $\mathrm{TiO}_{2}$ particles in the absence of irradiation showed only a slight decrease of the cell viability [169].

PC-12 cells treated with different concentrations $(1,10$, $50,100 \mu \mathrm{g} / \mathrm{mL}$ ) of nanostructured $\mathrm{TiO}_{2}(\mathrm{P} 25)$ showed a significant decrease of their viability in periods of $6,12,24$, and $48 \mathrm{~h}$ evincing an explicit dose effect and time dependence. It was suggested that $\mathrm{TiO}_{2}$ nanoparticles induce intracellular accumulation of reactive oxygen species and the apoptosis of PC-12 cells both of which increase with increasing concentration of $\mathrm{TiO}_{2}$ [172].

Chen and coworkers tested the cytotoxicity of various anatase nanostructures, possessing three different morphological structures to HeLa cells. OD anatase nanoparticles at a concentration of $125 \mu \mathrm{g} / \mathrm{mL}$ were found to decrease the cell viability to $80 \%$, whereas the viability of the cells was close to $100 \%$ when adding the 2D and 3D nanostructures at the same concentration.

By irradiating the treated cells with $8 \mathrm{~mW} / \mathrm{cm}^{2} \mathrm{UV}$ light for $1 \mathrm{~min}$ their mortality increased. These differences in toxicity may be related to the different uptake ability of unmodified structures of varying geometry into cells [168]. The studies of Jin et al. showed that weakly aggregated anatase nanoparticles with an average size of less than 100 $\mathrm{nm}$ induced significant toxicity in L929 cells at concentrations between $30 \mu \mathrm{g} / \mathrm{mL}$ and $600 \mu \mathrm{g} / \mathrm{mL}$. The cell shape became spherical accompanied with a cell shrinkage as the concentration of $\mathrm{TiO}_{2}$ nanoparticles increased. The thus treated cells were found to be necrotic and a significant increase in oxidative stress at higher $\mathrm{TiO}_{2}$ concentrations $(>60 \mu \mathrm{g} / \mathrm{mL})$ was observed [167].
Oxidative stress and the formation of reactive oxygen species (ROS) were shown to be integral parts of the key mechanisms of cellular defense after particle uptake. $\mathrm{TiO}_{2}$ nanoparticles evidently induce intracellular oxidative stress by disturbing the balance between oxidant and antioxidant processes [173].

However, other studies have shown that $\mathrm{TiO}_{2}$ nanomaterials do not exhibit any toxic effect to cells [170], [171]. Nine different powders and three different suspensions, all consisting of $\mathrm{TiO}_{2}$ nanoparticles have been tested concerning their toxicity to A-549, HEP-G2, PC-12, and NIH-3T3 cells. The particles differed in crystal structure, size and BET-surface area. In one of these studies, none of the tested particles showed any toxic effect on the cells in a concentration range between 100 and 1000 ppm, with the mitochondrial activity of the cells being the only parameter that was determined [170]. Another study investigating the toxic effect of suspensions of different $\mathrm{TiO}_{2}$ nanoparticles showed that some cells are more sensitive to particle exposure than others. The sensitivity of the employed cell lines was determined to be NIH-3T3 > A-549 > PC-12 > HEP-G2, with the NIH-3T3 being the most sensitive cell line. The highest applied $\mathrm{TiO}_{2}$ loading of $3125 \mu \mathrm{g} / \mathrm{cm}^{2}$ decreases the viability to $33 \%$ (NIH-3T3 cells cultivated with $\mathrm{TiO}_{2}$ particles with a hydrodynamic diameter of $144.0 \pm 23.7 \mathrm{~nm}$ ) in comparison to untreated cells. However, this study also showed that only very high particle doses exceeding 625 $\mu \mathrm{g} / \mathrm{cm}^{2}$ yield a significant decrease in viability. No additional decrease in the viability of cells was observed upon UV(A)-illumination [171].

Several studies have investigated the toxic effect of $\mathrm{ZnO}$ nanoparticles to MSTO cells and 3T3-cells [174], to SMMC-7721-cells, a hepatocellular cancer cell line [175], to HeLa and L929 cells [176], to PBMC (peripheral blood mononuclear) cells [177], to human skin fibroblasts [178] to primary mouse embryo fibroblasts, and to A-549 cells. Brunner et al. investigated the toxic effect of $\mathrm{ZnO}$ nanoparticles to MSTO- and fibroblasts (3T3-cells) [174] and found that the cells were no longer viable after 3 days exposure to zinc oxide (particle diameter $40 \mathrm{~nm}$ ) at concentrations exceeding $15 \mathrm{ppm}$. The authors assumed that the toxic effect of the $\mathrm{ZnO}$ nanoparticles is related to the solved $\mathrm{Zn}^{2+}$-ions. Furthermore, Lin et al. investigated the toxic effect of $\mathrm{ZnO}$ nanoparticles to A-549 cells at two different particle sizes $(70 \mathrm{~nm}$ and $420 \mathrm{~nm}$ ). They conclude that the exposure to both sizes of $\mathrm{ZnO}$ particles leads to dose- and time-dependent cytotoxicity reflected in oxidative stress, lipid peroxidation, cell membrane damage, and oxidative DNA damage. Neither free $\mathrm{Zn}^{2+}$ ions nor metal impurities appear to be major contributors of ROS induction [179] in contrast to the results of Brunner et al. [174].

Decksakulthorn and coworkers determined the $\mathrm{IC}_{50}$ values of $\mathrm{ZnO}$ particles (average particle sizes $70 \mathrm{~nm}$ ) to be 50 ppm for A-549 cells in contrast to the $\mathrm{IC}_{50}$ values of $\mathrm{TiO}_{2}$ 
particles (average particle size $50 \mathrm{~nm}$ ) being around 2700 ppm [178].

Studies of Hanley and coworkers demonstrate that $\mathrm{ZnO}$ nanoparticles induce toxicity in a cell-type specific manner that depends on the degree of particle-cellular membrane association, the phagocytic ability, and the inherent cellular capacities for ROS production. Monocytic cells displayed the greatest susceptibility and intracellular ROS production upon exposure to $\mathrm{ZnO}$ nanoparticle, followed by NK cells, and by lymphocytes, which displayed the highest resistance. Hanley et al. assumed that ROS formation is the major mechanism of $\mathrm{ZnO}$ nanoparticle-induced toxicity, with the generation of ROS and the cytotoxic effect occurring in a particle size-dependent manner, i.e., smaller particles display the greatest effect [177].

When studying $\mathrm{ZnO}$ particle sizes ranging from 20-100 $\mathrm{nm} \mathrm{Li}$ et al. did not find any particle size dependent toxic effect to SMMC-7721 cells [175].

The proliferation activity of L929 and HeLa cells has been found to be strongly deteriorated upon cultivation in the presence different doses of $\mathrm{ZnO}$ nanoparticle $(20 \mathrm{~nm})$ suspensions after $24 \mathrm{~h}$ and $48 \mathrm{~h}$ exposure. Concurrently, an increase in necrotic and apoptotic cells was observed after cultivation with $\mathrm{ZnO}$ particles [176].

\section{In vivo Studies of $\mathrm{TiO}_{2}$ and $\mathrm{ZnO}$ Nanoparticles}

The effect of various $\mathrm{TiO}_{2}$ particles in mice, rats, and hamsters after oral exposure and instillation [180], [181], [182], [183], [184], [185], [186], injection [187], [188] and inhalation [189], [181], [190], [191] has been studied in detail.

The inhalation studies with rats showed that a possible hazard and an inflammatory response do exist depending upon the particle characteristics. Lee and coworkers exposed rats to $\mathrm{TiO}_{2}$ by inhalation exposure with concentrations of $0,10,50$, and $250 \mathrm{mg} / \mathrm{m}^{3}$ for $6 \mathrm{~h} /$ day, 5 days/week for 2 years and found no abnormal clinical signs, no body weight changes, and no excess mortality in any exposed group. However, the exposed groups showed slight increases in the incidence of pneumonia, tracheitis, and rhinitis, and obvious hepatic damage and renal lesion in female mice [188]. $\mathrm{TiO}_{2}$ particles were found to be mainly retained in liver, kidney, spleen and lung [189]. Based on the excessive dust loading and overwhelmed clearance mechanisms in the lungs of rats exposed chronically at $250 \mathrm{mg} / \mathrm{m}^{3}$, the biological relevance of lung tumors to man appears to be negligible. Furthermore, no evidence exists to suggest that $\mathrm{TiO}_{2}$ causes lung tumors in humans [189], [192].

Warheit et al. showed in their inhalation studies with rats that the composition and the surface treatment of the nanoparticles can influence the toxicity of $\mathrm{TiO}_{2}$ particles in the lung. $\mathrm{TiO}_{2}$ formulations containing $7 \% \mathrm{Al}_{2} \mathrm{O}_{3}$ and $11 \%$ amorphous silica were found to produce adverse lung effects as compared to pure $\mathrm{TiO}_{2}$ [181].
Toxicological inhalation studies of Hext et al., with rats, mice, and hamsters being exposed to pigment grade $\mathrm{TiO}_{2}$ and ultrafine $\mathrm{TiO}_{2}(\mathrm{P} 25)$ for $6 \mathrm{~h} /$ day, 5 days/week for 13 weeks at concentrations of $0,10,50$, and $250 \mathrm{mg} / \mathrm{m}^{3}$ of $\mathrm{TiO}_{2}$ were performed to investigate whether rats are oversensitive to $\mathrm{TiO}_{2}$ compared to mice or hamsters. These epidemiology studies have been carried out to investigate whether a link exists between increased incidence of lung cancer and exposure to $\mathrm{TiO}_{2}$. The results of these studies do, however, not suggest that $\mathrm{TiO}_{2}$ nanoparticles exhibit any carcinogenic effect on the human lung [190]. In contrast to the study of Hext et al., Bermudez and coworkers reported that $\mathrm{TiO}_{2}$ exposure to rats in concentrations of 250 $\mathrm{mg} / \mathrm{m}^{3}$ can induce epithelial and fibroproliferative lesions as well as alveolar cell metaplasia using the pure rutile form of $\mathrm{TiO}_{2}$ for their inhalation studies [191].

Biodistribution experiments performed after oral administration of $\mathrm{TiO}_{2}$ nanoparticles to rats showed that the particles were retained in liver, spleen, kidney, and lung tissue indicating that $\mathrm{TiO}_{2}$ nanoparticles can be transported to other tissues and organs after uptake by the gastrointestinal tract [180], [184]. Following inhalation exposure the distribution of the particles was found to be the same [189]. Cui et al. reported that liver damage can be caused by oxidative stress after oral exposure of $\mathrm{TiO}_{2}(100 \%$ anatase $)$ nanoparticles to rats [182].

Hohr and coworkers investigated the acute inflammatory response and the cell damage induced by the intratracheal instillation of surface modified (hydrophilic and hydrophobic) fine (diameter $180 \mathrm{~nm})$ and ultrafine $(20 \pm 5 \mathrm{~nm}) \mathrm{TiO}_{2}$ particles for $16 \mathrm{~h}$ at equivalent mass ( $1 \mathrm{or} 6 \mathrm{mg}$ ) and surface doses $\left(100,500,600\right.$ and $\left.3000 \mathrm{~cm}^{2}\right)$ in rats. The results of Hohr et al. suggest that the surface area rather than the hydrophobicity of the surface determines the acute, pulmonary inflammation induced by both fine and ultrafine $\mathrm{TiO}_{2}$ [183], whereas Warheit et al. postulated in their studies that nanoscale particles do not exhibit any cytotoxicity or inflammation to the lung as compared to larger sized particles of similar chemical composition [186].

After intraperitoneal injection of high doses of $\mathrm{TiO}_{2}$ in rats $(150 \mathrm{mg} / \mathrm{kg})$ the production of $\mathrm{ROS}\left(\mathrm{O}^{-\bullet}\right.$ and $\left.\mathrm{H}_{2} \mathrm{O}_{2}\right)$ occurred in the liver indicating that this organ underwent oxidative stress which was found to be higher for nano anatase $\mathrm{TiO}_{2}$ than for bulk $\mathrm{TiO}_{2}$ [188]. Liu et al. observed that there was a serious damage of liver, kidney, and myocardium, an inflammatory response, and a metabolism imbalance of blood sugar and lipid after abdominal cavity injection of high doses of $\mathrm{TiO}_{2}$ to mice [187].

Acute toxicity to male mice after intratracheal injection of $\mathrm{ZnO}$ particles of different sizes $(10,30,100 \mathrm{~nm})$ at doses between 0.05 and $0.5 \mathrm{~g} / \mathrm{kg}$ body weight were also observed. Pathological examination showed the accumulation of $\mathrm{ZnO}$ particles after intratracheal injection in lung, spleen, pancreas, bone, and liver. At low doses, 30 and $100 \mathrm{~nm}$ sized $\mathrm{ZnO}$ particles induced a slight damage, whereas $10 \mathrm{~nm}$ 
sized particles caused a more serious lung and liver damage. At high doses, the $30 \mathrm{~nm}$ sized $\mathrm{ZnO}$ particles induced worse lung, liver, and pancreas injury [193].

Wang and coworkers investigated the acute oral toxicity of $\mathrm{ZnO}$ particles with different sizes $(20 \mathrm{~nm}$ and 120 $\mathrm{nm}$ ) at doses of $1,2,3,4$ and $5 \mathrm{~g} / \mathrm{kg}$ body weight. This study showed that following oral administration $\mathrm{ZnO}$ was mainly retained in bone, kidney, and pancreas. The results of blood measurements suggest that the increase in blood viscosity could be induced by high doses of $120 \mathrm{~nm}$ sized $\mathrm{ZnO}$ nanoparticles. For smaller particles $(20 \mathrm{~nm})$ lower concentrations caused the same effect [194].

\section{Conclusions}

Nanostructured materials are widely used in almost every sector of industry with photocatalysis being one important application field. Suitable semiconductors irradiated with UV- or visible light exhibit photocatalytic activity and can therefore be used for various applications, including the treatment of wastewater and the production of self-cleaning surfaces. Because of the common use of these materials it is important to investigate the possible effects of nanoparticulate photocatalysts to the environment and to human health.

Nanotoxicology is an emerging new subdiscipline of nanotechnology focusing on the toxic potential of nanostructured substances. Particularly difficult tasks within the field of nanotoxicology are the definition of the life cycle of these materials, the handling of the huge amount of natural nanoparticles and the lack of any logical labeling of nanomaterials. Nanoparticles exhibit other physical and chemical properties compared to their bulk counterparts. Therefore, a detailed characterization of these materials is certainly required. Shape, size, size distribution, agglomeration/aggregation, stability, solubility in different media, surface chemistry, composition, charge, crystal structure, zeta potential etc. of the particles have to be determined as a basis for the interpretation of the toxicity studies. To assess their environmental hazards the investigation of the toxic effect of nanomaterials to organisms living in water and to bacteria has to be carried out. For the assessment of the possible hazard to human health, in vitro and in vivo studies need to be performed.

The results of a wide selection of publications investigating the toxic effect of $\mathrm{TiO}_{2}$ and $\mathrm{ZnO}$, i.e., the two most commonly used photocatalysts, to different bacteria, water organisms, algae and plants as well as in vitro and in vivo studies with different sized and shaped $\mathrm{TiO}_{2}$ and $\mathrm{ZnO}$ particles are presented and discussed. This review shows that considerable differences in the published toxicity results do exist which can mainly be attributed to differences in the types of employed $\mathrm{TiO}_{2}$ and $\mathrm{ZnO}$ nanoparticles (size, shape, etc.) and the treatment methods demonstrating the importance of a suitable characterization of the particles.
In conclusion, it is obvious that the toxic effect of $\mathrm{TiO}_{2}$ nanoparticles can mainly be attributed to the production of reactive oxygen species, whereas the toxic effect caused by $\mathrm{ZnO}$ nanoparticles may be attributed to free $\mathrm{Zn}^{2+}$ ions.

\section{References}

[1] Feynman R., There's a plenty of room at the bottom. Engineering and Science, 23 (1960): 22-36.

[2] Schmid G., Nanotechnology: Key technology of the new century - Metal nanoparticles as single-electron switches. Chemie in Unserer Zeit, 39(1) (2005): 8-15.

[3] Murray C. B., Kagan C. R., Bawendi M. G., Synthesis and characterization of monodisperse nanocrystals and closepacked nanocrystal assemblies. Annual Review of Materials Science, 30 (2000): 545-610.

[4] Hiremane R., From Moore's Law to Intel innovationprediction to reality. Intel Magazine, (2005): 1-9.

[5] Leung K. C., Mendes P. M., Magonov S. N., Northrop B. H., Kim S., Patel K., Flood A. H., Tseng H. R., Stoddart J. F., Supramolecular self-assembly of dendronized polymers: reversible control of the polymer architectures through acid-base reactions. J Am Chem Soc, 128(33) (2006): 10707-15.

[6] Grevin B., Rannou P., Electrochemistry: arrays of polymer nanowires. Nat Mater, 3(8) (2004): 503-4.

[7] Salata O., Applications of nanoparticles in biology and medicine. J Nanobiotechnology, 2(1) (2004): 3.

[8] Ma J., Wong H. F., Kong L. B., Peng K. W., Biomimetic processing of nanocrystallite bioactive apatite coating on titanium. Nanotechnology, 14(6) (2003): 619-623.

[9] de la Isla A., Brostow W., Bujard B., Estevez M., Rodriguez J. R., Vargas S., Castano V. M., Nanohybrid scratch resistant coatings for teeth and bone viscoelasticity manifested in tribology. Materials Research Innovations, 7(2) (2003): $110-114$.

[10] Sanchez-Martin R. M., Alexander L., Muzerelle M., Cardenas-Maestre J. M., Tsakiridis A., Brickman J. M., Bradley M., Microsphere-mediated protein delivery into cells. Chembiochem, 10(9) (2009): 1453-6.

[11] Pantarotto D., Partidos C. D., Hoebeke J., Brown F., Kramer E., Briand J. P., Muller S., Prato M., Bianco A., Immunization with peptide-functionalized carbon nanotubes enhances virus-specific neutralizing antibody responses. Chemistry \& Biology, 10(10) (2003): 961-966.

[12] Bruchez M., Moronne M., Gin P., Weiss S., Alivisatos A. P., Semiconductor nanocrystals as fluorescent biological labels. Science, 281(5385) (1998): 2013-2016.

[13] Chan W. C., Nie S., Quantum dot bioconjugates for ultrasensitive nonisotopic detection. Science, 281(5385) (1998): 2016-8.

[14] Wang S. P., Mamedova N., Kotov N. A., Chen W., Studer J., Antigen/antibody immunocomplex from CdTe nanoparticle bioconjugates. Nano Letters, 2(8) (2002): 817-822.

[15] Edelstein R. L., Tamanaha C. R., Sheehan P. E., Miller M. M., Baselt D. R., Whitman L. J., Colton R. J., The BARC biosensor applied to the detection of biological warfare agents. Biosensors \& Bioelectronics, 14(10-11) (2000): 805-813. 
[16] Nam J. M., Thaxton C. S., Mirkin C. A., Nanoparticlebased bio-bar codes for the ultrasensitive detection of proteins. Science, 301(5641) (2003): 1884-1886.

[17] Molday R. S., MacKenzie D., Immunospecific ferromagnetic iron-dextran reagents for the labeling and magnetic separation of cells. J Immunol Methods, 52(3) (1982): 353 67.

[18] Shinkai M., Yanase M., Suzuki M., Honda H., Wakabayashi T., Yoshida J., Kobayashi T., Intracellular hyperthermia for cancer using magnetite cationic liposomes. Journal of Magnetism and Magnetic Materials, 194(1-3) (1999): 176-184.

[19] Mazzola L., Commercializing nanotechnology. Nature Biotechnology, 21(10) (2003): 1137-1143.

[20] Paull R., Wolfe J., Hebert P., Sinkula M., Investing in nanotechnology. Nature Biotechnology, 21(10) (2003): 1144 1147

[21] Vasilev K., Cook J., Griesser H. J. Antibacterial surfaces for biomedical devices. Expert Review of Medical Devices, 6(5) (2009): 553-567.

[22] Fujishima A., Rao T. N., Tryk D. A., Titanium dioxide photocatalysis. Journal of Photochemistry and Photobiology $C$ Photochemistry Reviews, 1 (2000): 1-21.

[23] Fox M. A., Dulay M. T., Heterogeneous Photocatalysis. Chemical Reviews, 93(1) (1993): 341-357.

[24] Patchkovskii S., Tse J. S., Yurchenko S. N., Zhechkov L., Heine T., Seifert G., Graphene nanostructures as tunable storage media for molecular hydrogen. Proceedings of the National Academy of Sciences of the United States of America, 102(30) (2005): 10439-10444.

[25] Zhang X. T., Fujishima A., Jin M., Emeline A. V., Murakami T., Double-layered TiO2-SiO2 nanostructured films with self-cleaning and antireflective properties. Journal of Physical Chemistry B, 110(50) (2006): 25142-25148.

[26] Hirai S., Takahashi N., Goto T., Lin S., Uemura T., Yu R., Kawada T. Functional food targeting the regulation of obesity-induced inflammatory responses and pathologies. Mediators Inflamm, (2010): 367838

[27] Malato S., Fernandez-Ibanez P., Maldonado M. I., Blanco J., Gernjak W., Decontamination and disinfection of water by solar photocatalysis: Recent overview and trends. Catalysis Today, 147(1) (2009): 1-59.

[28] Yu K. H., Chen J. H., Enhancing Solar Cell Efficiencies through 1-D Nanostructures. Nanoscale Research Letters, 4(1) (2009): 1-10.

[29] Fujishima A., Zhang X. T., Tryk D. A., TiO2 photocatalysis and related surface phenomena. Surface Science Reports, 63(12) (2008): 515-582

[30] Hoffmann M. R., Martin S. T., Choi W. Y., Bahnemann D. W., Environmental Applications of Semiconductor Photocatalysis. Chemical Reviews, 95(1) (1995): 69-96.

[31] Fujishima A., Rao T. N., Tryk D. A., Titanium dioxide photocatalysis. Journal of Photochemistry and Photobiology C: Photochemistry Reviews, 1(1) (2000): 1-21.

[32] Nosaka Y., Daimon T., Nosaka A. Y., Murakami Y., Singlet oxygen formation in photocatalytic $\mathrm{TiO} 2$ aqueous suspension. Physical Chemistry Chemical Physics, 6(11) (2004): 2917-2918.
[33] Tachikawa T., Fujitsuka M., Majima T., Mechanistic insight into the $\mathrm{TiO} 2$ photocatalytic reactions: Design of new photocatalysts. Journal of Physical Chemistry C, 111(14) (2007): 5259-5275.

[34] Kikuchi Y., Sunada K., Iyoda T., Hashimoto K., Fujishima A., Photocatalytic bactericidal effect of $\mathrm{TiO} 2$ thin films: Dynamic view of the active oxygen species responsible for the effect. Journal of Photochemistry and Photobiology aChemistry, 106(1-3) (1997): 51-56.

[35] Naito K., Tachikawa T., Fujitsuka M., Majima T., Singlemolecule fluorescence imaging of the remote $\mathrm{TiO} 2$ photocatalytic oxidation. Journal of Physical Chemistry B, 109(49) (2005): 23138-23140.

[36] Park J. S., Choi W., Enhanced remote photocatalytic oxidation on surface-fluorinated TiO2. Langmuir, 20(26) (2004): $11523-11527$.

[37] Tatsuma T., Tachibana S., Fujishima A., Remote oxidation of organic compounds by UV-irradiated $\mathrm{TiO} 2$ via the gas phase. Journal of Physical Chemistry B, 105(29) (2001): 6987-6992.

[38] Naito K., Tachikawa T., Cui S. C., Sugimoto A., Fujitsuka M., Majima T., Single-molecule detection of airborne singlet oxygen. Journal of the American Chemical Society, 128(51) (2006): 16430-16431.

[39] Tatsuma T., Tachibana S., Miwa T., Tryk D. A., Fujishima A., Remote bleaching of methylene blue by UV-irradiated $\mathrm{TiO} 2$ in the gas phase. Journal of Physical Chemistry B, 103(38) (1999): 8033-8035.

[40] Lee N. C., Choi W. Y., Solid phase photocatalytic reaction on the soot/TiO2 interface: The role of migrating $\mathrm{O} . \mathrm{H}$. radicals. Journal of Physical Chemistry B, 106(45) (2002): 11818-11822.

[41] Park J. S., Choi W. Y., Remote photocatalytic oxidation mediated by active oxygen species penetrating and diffusing through polymer membrane over surface fluorinated $\mathrm{TiO} 2$. Chemistry Letters, 34(12) (2005): 1630-1631.

[42] Cho S. M., Choi W. Y., Solid-phase photocatalytic degradation of P. V.C-TiO2 polymer composites. Journal of Photochemistry and Photobiology a-Chemistry, 143(2-3) (2001): 221-228

[43] Kawahara K., Ohko Y., Tatsuma T., Fujishima A., Surface diffusion behavior of photo-generated active species or holes on $\mathrm{TiO} 2$ photocatalysts. Physical Chemistry Chemical Physics, 5(21) (2003): 4764-4766.

[44] Haick H., Paz Y., "Dark" photocatalysis: The degradation of organic molecules anchored to dark microdomains of titanium dioxide. Chemphyschem, 4(6) (2003): 617-620.

[45] Ishikawa Y., Matsumoto Y., Nishida Y., Taniguchi S., Watanabe J., Surface treatment of silicon carbide using TiO2(I. V.) photocatalyst. Journal of the American Chemical Society, 125(21) (2003): 6558-6562.

[46] Tatsuma T., Kubo W., Fujishima A., Patterning of solid surfaces by photocatalytic lithography based on the remote oxidation effect of TiO2. Langmuir, 18(25) (2002): 9632 9634.

[47] Heller A., Chemistry and applications of photocatalytic oxidation of thin organic films. Accounts of Chemical Research, 28(12) (1995): 503-508. 
[48] Maeda K., Domen K., Photocatalytic Water Splitting: Recent Progress and Future Challenges. Journal of Physical Chemistry Letters, 1(18) (2010): 2655-2661.

[49] Kudo A., Miseki Y., Heterogeneous photocatalyst materials for water splitting. Chemical Society Reviews, 38(1) (2009): 253-278.

[50] Woodhouse M., Parkinson B. A., Combinatorial approaches for the identification and optimization of oxide semiconductors for efficient solar photoelectrolysis. Chemical Society Reviews, 38(1) (2009): 197-210.

[51] Garnweitner G., Grote C., In situ investigation of molecular kinetics and particle formation of water-dispersible titania nanocrystals. Phys Chem Chem Phys, 11(19) (2009): 3767-74.

[52] Zhang Z. B., Wang C. C., Zakaria R., Ying J. Y., Role of particle size in nanocrystalline $\mathrm{TiO} 2$-based photocatalysts. Journal of Physical Chemistry B, 102(52) (1998): 1087110878.

[53] Wang C., Ao Y. H., Wang P. F., Zhang S. H., Qian J., Hou J., A simple method for large-scale preparation of $\mathrm{ZnS}$ nanoribbon film and its photocatalytic activity for dye degradation. Applied Surface Science, 256(13) (2010): $4125-4128$.

[54] Harris C., Kamat P. V., Photocatalysis with CdSe Nanoparticles in Confined Media: Mapping Charge Transfer Events in the Subpicosecond to Second Timescales. A. C.S Nano, 3(3) (2009): 682-690.

[55] Honda H., Ishizaki A., Soma R., Hashimoto K., Fujishima A., Application of photocatalytic reactions caused by $\mathrm{TiO} 2$ film to improve the maintenance factor of lighting systems. Journal of the Illuminating Engineering Society, 27(1) (1998): 42-+.

[56] Cassar L., Photocatalysis of cementitious materials: Clean buildings and clean air. Mrs Bulletin, 29(5) (2004): 328331.

[57] Zhang X. T., Sato O., Taguchi M., Einaga Y., Murakami T., Fujishima A., Self-cleaning particle coating with antireflection properties. Chemistry of Materials, 17(3) (2005): 696-700.

[58] Tung W. S., Daoud W. A., Photocatalytic self-cleaning keratins: A feasibility study. Acta Biomaterialia, 5(1) (2009): $50-56$.

[59] Rupp F., Haupt M., Klostermann H., Kim H. S., Eichler M., Peetsch A., Scheideler L., Doering C., Oehr C., Wendel H. P., Sinn S., Decker E., von Ohle C., Geis-Gerstorfer $\mathrm{J}$., Multifunctional nature of UV-irradiated nanocrystalline anatase thin films for biomedical applications. Acta Biomater, 6(12): 4566-77.

[60] Yao Y., Ohko Y., Sekiguchi Y., Fujishima A., Kubota Y., Self-sterilization using silicone catheters coated with Ag and $\mathrm{TiO} 2$ nanocomposite thin film. Journal of Biomedical Materials Research Part B-Applied Biomaterials, 85B(2) (2008): 453-460.

[61] Nakamura H., Tanaka M., Shinohara S., Gotoh M., Karube I., Development of a self-sterilizing lancet coated with a titanium dioxide photocatalytic nano-layer for selfmonitoring of blood glucose. Biosens Bioelectron, 22(910) (2007): 1920-5.

[62] Pichat P., Disdier J., Hoang-Van C., Mas D., Goutailler G., Gaysse C., Purification/deodorization of indoor air and gaseous effluents by $\mathrm{TiO} 2$ photocatalysis. Catalysis Today, 63(2-4) (2000): 363-369.

[63] Ao C. H., Lee S. C., Enhancement effect of TiO2 immobilized on activated carbon filter for the photodegradation of pollutants at typical indoor air level. Applied Catalysis B-Environmental, 44(3) (2003): 191-205.

[64] Ao C. H., Lee S. C., Combination effect of activated carbon with $\mathrm{TiO} 2$ for the photodegradation of binary pollutants at typical indoor air level. Journal of Photochemistry and Photobiology A - Chemistry, 161(2-3) (2004): 131140 .

[65] Kim J. H., Seo G., Cho D. L., Choi B. C., Kim J. B., Park H. J., Kim M. W., Song S. J., Kim G. J., Kato S., Development of air purification device through application of thin-film photocatalyst. Catalysis Today, 111(3-4) (2006): 271-274.

[66] Grinshpun S. A., Adhikari A., Honda T., Kim K. Y., Toivola M., Rao K. S.R., Reponen T., Control of aerosol contaminants in indoor air: Combining the particle concentration reduction with microbial inactivation. Environmental Science \& Technology, 41(2) (2007): 606-612.

[67] Herrmann J. M., Heterogeneous photocatalysis: State of the art and present applications. Topics in Catalysis, 34(1-4) (2005): 49-65.

[68] Oller I., Gernjak W., Maldonado M. I., Perez-Estrada L. A., Sanchez-Perez J. A., Malato S., Solar photocatalytic degradation of some hazardous water-soluble pesticides at pilotplant scale. Journal of Hazardous Materials, 138(3) (2006): 507-517.

[69] Perez M. H., Penuela G., Maldonado M. I., Malato O., Fernandez-Ibanez P., Oller I., Gernjak W., Malato S., Degradation of pesticides in water using solar advanced oxidation processes. Applied Catalysis B-Environmental, 64(3-4) (2006): 272-281.

[70] Kositzi M., Poulios I., Malato S., Caceres J., Campos A., Solar photocatalytic treatment of synthetic municipal wastewater. Water Research, 38(5) (2004): 1147-1154.

[71] Maldonado M. I., Passarinho P. C., Oller I., Gernjak W., Fernandez P., Blanco J., Malato S., Photocatalytic degradation of E. U. priority substances: A comparison between $\mathrm{TiO} 2$ and Fenton plus photo-Fenton in a solar pilot plant. Journal of Photochemistry and Photobiology A - Chemistry, 185(2-3) (2007): 354-363.

[72] Maynard A. D., Aitken R. J., Butz T., Colvin V., Donaldson K., Oberdorster G., Philbert M. A., Ryan J., Seaton A., Stone V., Tinkle S. S., Tran L., Walker N. J., Warheit D. B., Safe handling of nanotechnology. Nature, 444(7117) (2006): 267-269.

[73] Tsuji J. S., Maynard A. D., Howard P. C., James J. T., Lam C. W., Warheit D. B., Santamaria A. B., Research strategies for safety evaluation of nanomaterials, part IV: Risk assessment of nanoparticles. Toxicological Sciences, 89(1) (2006): 42-50.

[74] Oberdorster G. Safety assessment for nanotechnology and nanomedicine: concepts of nanotoxicology. J Intern Med, 267(1): 89-105.

[75] Oberdorster G., Oberdorster E., Oberdorster J., Nanotoxicology: an emerging discipline evolving from studies of ultrafine particles. Environ Health Perspect, 113(7) (2005): $823-39$. 
[76] Oberdorster G., Stone V., Donaldson K., Toxicology of nanoparticles: A historical perspective. Nanotoxicology, 1(1) (2007): 2-25.

[77] Maynard A. D., Aitken R. J., Assessing exposure to airborne nanomaterials: Current abilities and future requirements. Nanotoxicology, 1(1) (2007): 26-41.

[78] Seipenbusch M., Binder A., Kasper G., Temporal evolution of nanoparticle aerosols in workplace exposure. Ann Occup Hyg, 52(8) (2008): 707-16.

[79] Fujitani Y., Kobayashi T., Arashidani K., Kunugita N., Suemura K., Measurement of the physical properties of aerosols in a fullerene factory for inhalation exposure assessment. J Occup Environ Hyg, 5(6) (2008): 380-9.

[80] Han J. H., Lee E. J., Lee J. H., So K. P., Lee Y. H., Bae G. N., Lee S. B., Ji J. H., Cho M. H., Yu I. J., Monitoring multiwalled carbon nanotube exposure in carbon nanotube research facility. Inhalation Toxicology, 20(8) (2008): 741749.

[81] Mitsakou C., Helmis C., Housiadas C., Eulerian modelling of lung deposition with sectional representation of aerosol dynamics. Journal of Aerosol Science, 36(1) (2005): 7594.

[82] Aitken R., RS Report Nanoscience and nanotechnologie, (2004)

[83] Gwinn M. R., Tran L., Risk management of nanomaterials. Wiley Interdisciplinary Reviews-Nanomedicine and Nanobiotechnology, 2(2) (2010): 130-137.

[84] Teeguarden J. G., Hinderliter P. M., Orr G., Thrall B. D., Pounds J. G., Particokinetics in vitro: Dosimetry considerations for in vitro nanoparticle toxicology assessments (vol 95, pg 300, 2007). Toxicological Sciences, 97(2) (2007): 614-614.

[85] Lam C. W., James J. T., McCluskey R., Hunter R. L., Pulmonary toxicity of single-wall carbon nanotubes in mice 7 and 90 days after intratracheal instillation. Toxicological Sciences, 77(1) (2004): 126-134.

[86] Warheit D. B., Laurence B. R., Reed K. L., Roach D. H., Reynolds G. A. M., Webb T. R., Comparative pulmonary toxicity assessment of single-wall carbon nanotubes in rats. Toxicological Sciences, 77(1) (2004): 117-125.

[87] Helland A., Wick P., Koehler A., Schmid K., Som C., Reviewing the environmental and human health knowledge base of carbon nanotubes. Environmental Health Perspectives, 115(8) (2007): 1125-1131.

[88] Oberdorster G., Ferin J., Gelein R., Soderholm S. C., Finkelstein J., Role of the alveolar macrophage in lung injury: studies with ultrafine particles. Environ Health Perspect, 97 (1992):193-9.

[89] Donaldson K., Tran L., Jimenez L. A., Duffin R., Newby D. E., Mills N., MacNee W., Stone V., Combustion-derived nanoparticles (2005): a review of their toxicology following inhalation exposure. Part Fibre Toxicol, 2(10.

[90] Dybdahl M., Risom L., Bornholdt J., Autrup H., Loft S., Wallin H., Inflammatory and genotoxic effects of diesel particles in vitro and in vivo. Mutation Research-Genetic Toxicology and Environmental Mutagenesis, 562(1-2) (2004): 119-131.

[91] Hirano S., Furuyama A., Koike E., Kobayashi T., Oxidative-stress potency of organic extracts of diesel ex- haust and urban fine particles in rat heart microvessel endothelial cells. Toxicology, 187(2-3) (2003): 161-170.

[92] McNeilly J. D., Heal M. R., Beverland I. J., Howe A., Gibson M. D., Hibbs L. R., MacNee W., Donaldson K., Soluble transition metals cause the pro-inflammatory effects of welding fumes in vitro. Toxicology and Applied Pharmacology, 196(1) (2004): 95-107.

[93] Renwick L. C., Brown D., Clouter A., Donaldson K., Increased inflammation and altered macrophage chemotactic responses caused by two ultrafine particle types. Occupational and Environmental Medicine, 61(5) (2004): 442 447.

[94] Gilmour M. I., O’Connor S., Dick C. A.J., Miller C. A., Linak W. P., Differential pulmonary inflammation and in vitro cytotoxicity of size-fractionated fly ash particles from pulverized coal combustion. Journal of the Air \& Waste Management Association, 54(3) (2004): 286-295.

[95] Lockman P. R., Koziara J. M., Mumper R. J., Allen D. D., Nanoparticle surface charges alter blood-brain barrier integrity and permeability. J Drug Target, 12(9-10) (2004): 635-41.

[96] Lademann J., Weigmann H., Rickmeyer C., Barthelmes H., Schaefer H., Mueller G., Sterry W., Penetration of titanium dioxide microparticles in a sunscreen formulation into the horny layer and the follicular orifice. Skin Pharmacol Appl Skin Physiol, 12(5) (1999): 247-56.

[97] Alvarez-Roman R., Naik A., Kalia Y., Guy R. H., Fessi H., Skin penetration and distribution of polymeric nanoparticles. Journal of Controlled Release, 99(1) (2004): 53-62.

[98] Zvyagin A. V., Zhao X., Gierden A., Sanchez W., Ross J. A., Roberts M. S., Imaging of zinc oxide nanoparticle penetration in human skin in vitro and in vivo. $J$ Biomed Opt, 13(6) (2008): 064031.

[99] Cross S. E., Innes B., Roberts M. S., Tsuzuki T., Robertson T. A., McCormick P., Human skin penetration of sunscreen nanoparticles: In-vitro assessment of a novel micronized zinc oxide formulation. Skin Pharmacology and Physiology, 20(3) (2007): 148-154.

[100] Mortensen L. J., Oberdorster G., Pentland A. P., Delouise L. A., In vivo skin penetration of quantum dot nanoparticles in the murine model: the effect of UVR. Nano Lett, 8(9) (2008): 2779-87.

[101] Ito A., Shinkai M., Honda H., Kobayashi T., Medical application of functionalized magnetic nanoparticles. Journal of Bioscience and Bioengineering, 100(1) (2005): 1-11.

[102] Gopee N. V., Roberts D. W., Webb P., Cozart C. R., Siitonen P. H., Warbritton A. R., Yu W. W., Colvin V. L., Walker N. J., Howard P. C., Migration of intradermally injected quantum dots to sentinel organs in mice. Toxicol Sci, 98(1) (2007): 249-57.

[103] Chithrani B. D., Ghazani A. A., Chan W. C., Determining the size and shape dependence of gold nanoparticle uptake into mammalian cells. Nano Lett, 6(4) (2006): 662-8.

[104] Choi H. S., Liu W., Misra P., Tanaka E., Zimmer J. P., Ipe B. I., Bawendi M. G., Frangioni J. V., Renal clearance of quantum dots. Nature Biotechnology, 25(10) (2007): 11651170 .

[105] Fischer H. C., Liu L. C., Pang K. S., Chan W. C.W., Pharmacokinetics of nanoscale quantum dots: In vivo distribution, sequestration, and clearance in the rat. Advanced Functional Materials, 16(10) (2006): 1299-1305. 
[106] Nel A., Xia T., Madler L., Li N., Toxic potential of materials at the nanolevel. Science, 311(5761) (2006): 622-627.

[107] Sayes C. M., Gobin A. M., Ausman K. D., Mendez J., West J. L., Colvin V. L., Nano-C-60 cytotoxicity is due to lipid peroxidation. Biomaterials, 26(36) (2005): 7587-7595.

[108] Ipe B. I., Lehnig M., Niemeyer C. M., On the generation of free radical species from quantum dots. Small, 1(7) (2005): 706-709.

[109] Lovric J., Cho S. J., Winnik F. M., Maysinger D., Unmodified cadmium telluride quantum dots induce reactive oxygen species formation leading to multiple organelle damage and cell death. Chemistry \& Biology, 12(11) (2005): 1227 1234.

[110] Tsay J. M., Michalet X., New light on quantum dot cytotoxicity. Chemistry \& Biology, 12(11) (2005): 1159-1161.

[111] Klein J., Probing the interactions of proteins and nanoparticles. Proceedings of the National Academy of Sciences of the United States of America, 104(7) (2007): 2029-2030.

[112] Cedervall T., Lynch I., Lindman S., Berggard T., Thulin E., Nilsson H., Dawson K. A., Linse S., Understanding the nanoparticle-protein corona using methods to quantify exchange rates and affinities of proteins for nanoparticles. Proceedings of the National Academy of Sciences of the United States of America, 104(7) (2007): 2050-2055.

[113] Petkovic J., Zegura B., Stevanovic M., Drnovsek N., Uskokovic D., Novak S., Filipic M., DNA damage and alterations in expression of DNA damage responsive genes induced by $\mathrm{TiO}(2)$ nanoparticles in human hepatoma HepG2 cells. Nanotoxicology,

[114] Ku S., Yan F., Wang Y., Sun Y., Yang N., Ye L. The bloodbrain barrier penetration and distribution of P. E. Gylated fluorescein-doped magnetic silica nanoparticles in rat brain. Biochem Biophys Res Commun, 394(4): 871-6.

[115] Meißner T., Potthoff A., Richter V., Suspension characterization as important key for toxicological investigations. Journal of Physics, Conference Series 170 (Nanosafe 2008).

[116] Allouni Z. E., Cimpan M. R., Hol P. J., Skodvin T., Gjerdet N. R. 2009, Agglomeration and sedimentation of $\mathrm{TiO} 2$ nanoparticles in cell culture medium. Colloids and Surfaces B-Biointerfaces, 68(1) (2009): 83-87.

[117] Buford M. C., Hamilton R. F., Jr., Holian A., A comparison of dispersing media for various engineered carbon nanoparticles. Part Fibre Toxicol, 4: (2007)6.

[118] Kuhnel D., Busch W., Meissner T., Springer A., Potthoff A., Richter V., Gelinsky M., Scholz S., Schirmer K., Agglomeration of tungsten carbide nanoparticles in exposure medium does not prevent uptake and toxicity toward a rainbow trout gill cell line. Aquat Toxicol, 93(2-3) (2009): 919.

[119] Chen Z. P., Xu R. Z., Zhang Y., Gu N., Effects of Proteins from Culture Medium on Surface Property of SilanesFunctionalized Magnetic Nanoparticles. Nanoscale Res Lett, 4(3) (2008): 204-209.

[120] Ji Z., Jin X., George S., Xia T., Meng H., Wang X., Suarez E., Zhang H., Hoek E. M., Godwin H., Nel A. E., Zink J. I., Dispersion and stability optimization of $\mathrm{TiO} 2$ nanoparticles in cell culture media. Environ Sci Technol, 44(19): 730914.
[121] Kan A. T., Tomson M. B., Ground-Water Transport of Hydrophobic Organic-Compounds in the Presence of Dissolved Organic-Matter. Environmental Toxicology and Chemistry, 9(3) (1990): 253-263.

[122] Jacoby W. A., Maness P. C., Wolfrum E. J., Blake D. M., Fennell J. A., Mineralization of bacterial cell mass on a photocatalytic surface in air. Environmental Science \& Technology, 32(17) (1998): 2650-2653.

[123] Matsunaga T., Tomoda R., Nakajima T., Wake H., Photoelectrochemical Sterilization of Microbial-Cells by Semiconductor Powders. Fems Microbiology Letters, 29(1-2) (1985): 211-214.

[124] Coleman H. M., Marquis C. P., Scott J. A., Chin S. S., Amal R., Bactericidal effects of titanium dioxide-based photocatalysts. Chemical Engineering Journal, 113(1) (2005): 5563.

[125] Srinivasan C., Somasundaram N., Bactericidal and detoxification effects of irradiated semiconductor catalyst, $\mathrm{TiO} 2$. Current Science, 85(10) (2003): 1431-1438.

[126] Chen F. N., Yang X. D., Xu F. F., Wu Q., Zhang Y. P., Correlation of Photocatalytic Bactericidal Effect and Organic Matter Degradation of TiO2 Part I: Observation of Phenomena. Environmental Science \& Technology, 43(4) (2009): $1180-1184$.

[127] Liu H. L., Yang T. C.K., Photocatalytic inactivation of Escherichia coli and Lactobacillus helveticus by $\mathrm{ZnO}$ and $\mathrm{TiO} 2$ activated with ultraviolet light. Process Biochemistry, 39(4) (2003): 475-481.

[128] Armon R., Laot N., Neeman I., Photocatalytic inactivation of different bacteria and bacteriophages in drinking water at different $\mathrm{TiO} 2$ concentration with or without exposure to O2. Journal of Advanced Oxidation, 3 (1998): 145-150.

[129] Biguzzi M., Shama G., Effect of Titanium-Dioxide Concentration on the Survival of Pseudomonas-Stutzeri during Irradiation with near-Ultraviolet Light. Letters in Applied Microbiology, 19(6) (1994): 458-460.

[130] Pham H. N., Mcdowell T., Wilkins E., PhotocatalyticallyMediated Disinfection of Water Using Tio2 as a Catalyst and Spore-Forming Bacillus-Pumilus as a Model. Journal of Environmental Science and Health Part a-Environmental Science and Engineering \& Toxic and Hazardous Substance Control, 30(3) (1995): 627-636.

[131] Kuhn K. P., Chaberny I. F., Massholder K., Stickler M., Benz V. W., Sonntag H. G., Erdinger L., Disinfection of surfaces by photocatalytic oxidation with titanium dioxide and UVA light. Chemosphere, 53(1) (2003): 71-7.

[132] Gogniat G., Thyssen M., Denis M., Pulgarin C., Dukan S., The bactericidal effect of $\mathrm{TiO} 2$ photocatalysis involves adsorption onto catalyst and the loss of membrane integrity. Fems Microbiology Letters, 258(1) (2006): 18-24.

[133] Yao K. S., Wang D. Y., Chang C. Y., Weng K. W., Yang L. Y., Lee S. J., Cheng T. C., Hwang C. C., Photocatalytic disinfection of phytopathogenic bacteria by dye-sensitized $\mathrm{TiO} 2$ thin film activated by visible light. Surface \& Coatings Technology, 202(4-7) (2007): 1329-1332.

[134] Yao K. S., Wang D. Y., Ho W. Y., Yan J. J., Tzeng K. C., Photocatalytic bactericidal effect of $\mathrm{TiO} 2$ thin film on plant pathogens. Surface \& Coatings Technology, 201(15) (2007): 6886-6888

[135] Huang Z. B., Zheng X., Yan D. H., Yin G. F., Liao X. M., Kang Y. Q., Yao Y. D., Huang D., Hao B. Q., Toxicological 
effect of $\mathrm{ZnO}$ nanoparticles based on bacteria. Langmuir, 24(8) (2008): 4140-4144.

[136] Adams L. K., Lyon D. Y., Alvarez P. J.J., Comparative ecotoxicity of nanoscale $\mathrm{TiO} 2, \mathrm{SiO} 2$, and $\mathrm{ZnO}$ water suspensions. Water Research, 40(19) (2006): 3527-3532.

[137] Zhang L. L., Jiang Y. H., Ding Y. L., Povey M., York D., Investigation into the antibacterial behaviour of suspensions of $\mathrm{ZnO}$ nanoparticles ( $\mathrm{ZnO}$ nanofluids). Journal of Nanoparticle Research, 9(3) (2007): 479-489.

[138] Roselli M., Finamore A., Garaguso I., Britti M. S., Mengheri E., Zinc oxide protects cultured enterocytes from the damage induced by Escherichia coli. Journal of Nutrition, 133(12) (2003): 4077-4082.

[139] Jones N., Ray B., Ranjit K. T., Manna A. C., Antibacterial activity of $\mathrm{ZnO}$ nanoparticle suspensions on a broad spectrum of microorganisms. Fems Microbiology Letters, 279(1) (2008): 71-76.

[140] Sunada K., Kikuchi Y., Hashimoto K., Fujishima A., Bactericidal and detoxification effects of $\mathrm{TiO} 2$ thin film photocatalysts. Environmental Science \& Technology, 32(5) (1998): 726-728.

[141] Sunada K., Watanabe T., Hashimoto K., Studies on photokilling of bacteria on $\mathrm{TiO} 2$ thin film. Journal of Photochemistry and Photobiology a-Chemistry, 156(1-3) (2003): 227-233.

[142] Brayner R., Ferrari-Iliou R., Brivois N., Djediat S., Benedetti M. F., Fievet F., Toxicological impact studies based on Escherichia coli bacteria in ultrafine $\mathrm{ZnO}$ nanoparticles colloidal medium. Nano Letters, 6(4) (2006): 866-870.

[143] Gaballa A., Helmann J. D., Identification of a zinc-specific metalloregulatory protein, Zur, controlling zinc transport operons in Bacillus subtilis. J Bacteriol, 180(22) (1998): 5815-21.

[144] Lindsay J. A., Foster S. J., zur: a Zn(2+)-responsive regulatory element of Staphylococcus aureus. Microbiology, 147(Pt 5) (2001): 1259-66.

[145] Hund-Rinke K., Simon M., Ecotoxic effect of photocatalytic active nanoparticles ( $\mathrm{TiO} 2)$ on algae and daphnids. Environ Sci Pollut Res Int, 13(4) (2006): 225-32.

[146] Lovern S. B., Klaper R., Daphnia magna mortality when exposed to titanium dioxide and fullerene (C60) nanoparticles. Environ Toxicol Chem, 25(4) (2006): 1132-7.

[147] Velzeboer I., Hendriks A. J., Ragas A. M., Van de Meent D., Aquatic ecotoxicity tests of some nanomaterials. Environ Toxicol Chem, 27(9) (2008): 1942-7.

[148] Ruiz M. J., Lopez-Jaramillo L., Redondo M. J., Font G., Toxicity assessment of pesticides using the microtox test: application to environmental samples. Bull Environ Contam Toxicol, 59(4) (1997): 619-25.

[149] Pena-Vazquez E., Perez-Conde C., Costas E., MorenoBondi M. C. Development of a microalgal P. A.M test method for $\mathrm{Cu}(\mathrm{II})$ in waters: comparison of using spectrofluorometry. Ecotoxicology, 19(6): 1059-65.

[150] Pieters B., Bosman-Meijerman D., Steenbergen E., van de Brandhof E-J., van Beelen P., van de Grinten E., Verweij W., Kraak M., Ecological quality assessment of Dutch surface waters using a new bioassays with the cladoceran Chydorus spaericus. Proc Neth Entomol Soc Meet, 19 (2008): 157-164.
[151] Schmitt H., Martinali B., Van Beelen P., Seinen W., On the limits of toxicant-induced tolerance testing: cotolerance and response variation of antibiotic effects. Environ Toxicol Chem, 25(7) (2006): 1961-8.

[152] Aruoja V., Dubourguier H. C., Kasemets K., Kahru A., Toxicity of nanoparticles of $\mathrm{CuO}$., $\mathrm{ZnO}$ and $\mathrm{TiO} 2$ to microalgae Pseudokirchneriella subcapitata. Sci Total Environ, 407(4) (2009): 1461-8.

[153] Heinlaan M., Ivask A., Blinova I., Dubourguier H. C., Kahru A., Toxicity of nanosized and bulk $\mathrm{ZnO}$., $\mathrm{CuO}$ and $\mathrm{TiO} 2$ to bacteria Vibrio fischeri and crustaceans Daphnia magna and Thamnocephalus platyurus. Chemosphere, 71(7) (2008): 1308-16.

[154] Miller R. J., Lenihan H. S., Muller E. B., Tseng N., Hanna S. K., Keller A. A., Impacts of metal oxide nanoparticles on marine phytoplankton. Environ Sci Technol, 44(19): 732934.

[155] Sunda W. G., Price N. M., Morel F. M. M., Trace metal ion buffers and their use in culture studies. Algal Cutlturing Techniques (2005), 35-64.

[156] Sunda W. G., Huntsman S. A., Antagonisms between cadmium and zinc toxicity and manganese limitation in a coastal diatom. Limnology and Oceanography, 41(3) (1996): 373-387.

[157] Stauber J. L., Florence T. M., Mechanism of Toxicity of Zinc to the Marine Diatom Nitzschia-Closterium. Marine Biology, 105(3) (1990): 519-524.

[158] Mortimer M., Kasemets K., Kahru A., Toxicity of ZnO and $\mathrm{CuO}$ nanoparticles to ciliated protozoa Tetrahymena thermophila. Toxicology, 269(2-3) (2010): 182-189.

[159] Lin D. H., Xing B. S., Root uptake and phytotoxicity of $\mathrm{ZnO}$ nanoparticles. Environmental Science \& Technology, 42(15) (2008): 5580-5585.

[160] Picatonotto T., Vione D., Carlotti M. E., Gallarate M., Photocatalytic activity of inorganic sunscreens. Journal of Dispersion Science and Technology, 22(4) (2001): 381-386.

[161] Hidaka H., Horikoshi S., Serpone N., Knowland J., In vitro photochemical damage to DNA, RNA and their bases by an inorganic sunscreen agent on exposure to UVA and UVB radiation. Journal of Photochemistry and Photobiology aChemistry, 111(1-3) (1997): 205-213.

[162] Lu N. H., Zhu Z. N., Zhao X. Q., Tao R., Yang X. L., Gao Z. H., Nano titanium dioxide photocatalytic protein tyrosine nitration: A potential hazard of $\mathrm{TiO} 2$ on skin. Biochemical and Biophysical Research Communications, 370(4) (2008): 675-680.

[163] Herrling T., Jung K., Fuchs J., Measurements of UVgenerated free radicals/reactive oxygen species (ROS) in skin. Spectrochimica Acta Part A - Molecular and Biomolecular Spectroscopy, 63(4) (2006): 840-845.

[164] Brezova V., Gabcova S., Dvoranova D., Stasko A., Reactive oxygen species produced upon photoexcitation of sunscreens containing titanium dioxide (an EPR study). Journal of Photochemistry and Photobiology B - Biology, 79(2) (2005): 121-134.

[165] Dunford R., Salinaro A., Cai L. Z., Serpone N., Horikoshi S., Hidaka H., Knowland J., Chemical oxidation and DNA damage catalysed by inorganic sunscreen ingredients. Febs Letters, 418(1-2) (1997): 87-90. 
[166] Jin C., Tang Y., Yang F. G., Li X. L., Xu S., Fan X. Y., Huang Y. Y., Yang Y. J. Cellular Toxicity of TiO(2) Nanoparticles in Anatase and Rutile Crystal Phase. Biol Trace Elem Res,

[167] Jin C. Y., Zhu B. S., Wang X. F., Lu Q. H., Cytotoxicity of titanium dioxide nanoparticles in mouse fibroblast cells. Chemical Research in Toxicology, 21(9) (2008): 18711877.

[168] Chen J. Y., Zhou H. J., Santulli A. C., Wong S. S., Evaluating Cytotoxicity and Cellular Uptake from the Presence of Variously Processed TiO2 Nanostructured Morphologies. Chemical Research in Toxicology, 23(5) (2010): 871-879.

[169] Cai R. X., Kubota Y., Shuin T., Sakai H., Hashimoto K., Fujishima A., Induction of Cytotoxicity by Photoexcited Tio2 Particles. Cancer Research, 52(8) (1992): 2346-2348.

[170] Wagner S., Münzer S., Behrens P., Scheper T., Bahnemann D. W., Kasper C., Cytotoxicity of Titanium and Silicon Dioxide Nanoparticles. Journal of Physics, Conference Series 170 (Nanosafe 2008).

[171] Bloh J. Z., Wagner S., Bahnemann D. W., Scheper T., Kasper C. 2010, Studies on cytotoxicity of photocatalytic active titanium dioxide nanoparticles. Chemie Ingenieur Technik, 82(3) (2009): 335-341.

[172] Liu S. C., Xu L. J., Zhang T., Ren G. G., Yang Z., Oxidative stress and apoptosis induced by nanosized titanium dioxide in PC12 cells. Toxicology, 267(1-3) (2010): 172-177.

[173] Gurr J. R., Wang A. S. S., Chen C. H., Jan K. Y., Ultrafine titanium dioxide particles in the absence of photoactivation can induce oxidative damage to human bronchial epithelial cells. Toxicology, 213(1-2) (2005): 66-73.

[174] Brunner T. J., Wick P., Manser P., Spohn P., Grass R. N., Limbach L. K., Bruinink A., Stark W. J., In vitro cytotoxicity of oxide nanoparticles: Comparison to asbestos, silica, and the effect of particle solubility. Environmental Science \& Technology, 40(14) (2006): 4374-4381.

[175] Li J. Y., Guo D. D., Wang X. M., Wang H. P., Jiang H., Chen B. A., The Photodynamic Effect of Different Size $\mathrm{ZnO}$ Nanoparticles on Cancer Cell Proliferation In Vitro. Nanoscale Research Letters, 5(6) (2010): 1063-1071.

[176] Zheng Y. F., Li R. Z., Wang Y. D., In Vitro and in Vivo Biocompatibility Studies of $\mathrm{ZnO}$ Nanoparticles. International Journal of Modern Physics B, 23(6-7) (2009): 1566-1571.

[177] Hanley C., Thurber A., Hanna C., Punnoose A., Zhang J. H., Wingett D. G., The Influences of Cell Type and ZnO Nanoparticle Size on Immune Cell Cytotoxicity and Cytokine Induction. Nanoscale Research Letters, 4(12) (2009): 1409-1420.

[178] Decksakulthorn F., Hayes A., Bakand S., Joeng L., Winder C., In vitro cytotoxicity assessment of selected nanoparticles using human skin fibroblasts. AATEX, Special Issue (2007)) (2007): 397-400.

[179] Lin W. S., Xu Y., Huang C. C., Ma Y. F., Shannon K. B., Chen D. R., Huang Y. W., Toxicity of nano- and microsized $\mathrm{ZnO}$ particles in human lung epithelial cells. Journal of Nanoparticle Research, 11(1) (2009): 25-39.

[180] Wang J., Zhou G., Chen C., Yu H., Wang T., Ma Y., Jia G., Gao Y., Li B., Sun J., Li Y., Jiao F., Zhao Y., Chai Z., Acute toxicity and biodistribution of different sized titanium dioxide particles in mice after oral administration. Toxicol Lett, 168(2) (2007): 176-85.
[181] Warheit D. B., Brock W. J., Lee K. P., Webb T. R., Reed K. L., Comparative pulmonary toxicity inhalation and instillation studies with different $\mathrm{TiO} 2$ particle formulations: impact of surface treatments on particle toxicity. Toxicol Sci, 88(2) (2005): 514-24.

[182] Cui Y., Gong X., Duan Y., Li N., Hu R., Liu H., Hong M., Zhou M., Wang L., Wang H., Hong F. Hepatocyte apoptosis and its molecular mechanisms in mice caused by titanium dioxide nanoparticles. J Hazard Mater, 183(1-3): 874-80.

[183] Hohr D., Steinfartz Y., Schins R. P., Knaapen A. M., Martra G., Fubini B., Borm P. J., The surface area rather than the surface coating determines the acute inflammatory response after instillation of fine and ultrafine $\mathrm{TiO} 2$ in the rat. Int $J$ Hyg Environ Health, 205(3) (2002): 239-44.

[184] Jani P. U., Mccarthy D. E., Florence A. T., TitaniumDioxide (Rutile) Particle Uptake from the Rat Gi Tract and Translocation to Systemic Organs after OralAdministration. International Journal of Pharmaceutics, 105(2) (1994): 157-168.

[185] Duan Y., Liu J., Ma L., Li N., Liu H., Wang J., Zheng L., Liu C., Wang X., Zhao X., Yan J., Wang S., Wang H., Zhang X., Hong F. Toxicological characteristics of nanoparticulate anatase titanium dioxide in mice. Biomaterials, 31(5): 894-9.

[186] Warheit D. B., Webb T. R., Sayes C. M., Colvin V. L., Reed K. L., Pulmonary instillation studies with nanoscale $\mathrm{TiO} 2$ rods and dots in rats: toxicity is not dependent upon particle size and surface area. Toxicol Sci, 91(1) (2006): 227-36.

[187] Liu H., Ma L., Zhao J., Liu J., Yan J., Ruan J., Hong F., Biochemical toxicity of nano-anatase $\mathrm{TiO} 2$ particles in mice. Biol Trace Elem Res, 129(1-3) (2009): 170-80.

[188] Liu H., Ma L., Liu J., Zhao J., Yan J., Hong F., Toxicity of nano-anatase $\mathrm{TiO} 2$ to mice: Liver injury oxidative stress. Toxicological and Environmental Chemistry, 92 (2010): 175-186.

[189] Lee K. P., Trochimowicz H. J., Reinhardt C. F., Pulmonary response of rats exposed to titanium dioxide (TiO2) by inhalation for two years. Toxicol Appl Pharmacol, 79(2) (1985): 179-92.

[190] Hext P. M., Tomenson J. A., Thompson P., Titanium dioxide: inhalation toxicology and epidemiology. Ann Occup Hyg, 49(6) (2005): 461-72.

[191] Bermudez E., Mangum J. B., Asgharian B., Wong B. A., Reverdy E. E., Janszen D. B., Hext P. M., Warheit D. B., Everitt J. I., Long-term pulmonary responses of three laboratory rodent species to subchronic inhalation of pigmentary titanium dioxide particles. Toxicol Sci, 70(1) (2002): 86-97.

[192] Uragoda C. G., Pinto M. R., An investigation into the health of workers in an ilmenite extracting plant. Med J Aust, 1(4) (1972): 167-9.

[193] Song W., Zhang J., Acute toxicological impact of nanoand submicro-scaled zinc oxide powder on healthy adult mice. Bioinformatics and Biomedical Engineering 4th International Conference 2010, (1-4).

[194] Wang B., Feng W. Y., Wang M., Wang T. C., Gu Y. Q., Zhu M. T., Ouyang H., Shi J. W., Zhang F., Zhao Y. L., Chai Z. F., Wang H. F., Wang J., Acute toxicological impact of nano- and submicro-scaled zinc oxide powder on healthy adult mice. Journal of Nanoparticle Research, 10(2) (2008): 263-276. 


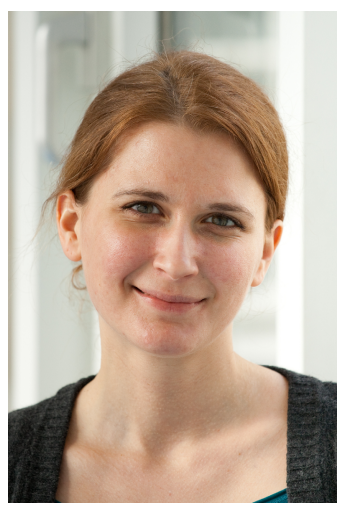

Stefanie Wagner is a member of the research groups of Prof. Bahnemann and PD Dr. Cornelia Kasper at the Institute of Technical Chemistry of the Leibniz University Hannover since 2007. After finishing her Diploma degree in Chemistry with the diploma thesis titled: "Cytotoxicity of titanium dioxide nanoparticles", she is currently working on her PhD thesis with the title "Cytotoxic effects of different nanoparticles on mammalian cells".

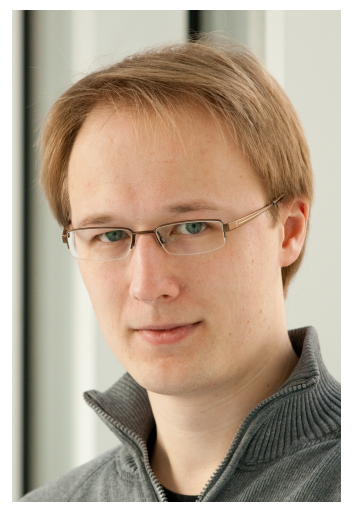

Jonathan Z. Bloh is a member of the research group of Prof. Bahnemann at the Institute of Technical Chemistry of the Leibniz University Hannover since 2008. After finishing his Master's degree in Life Science with the master thesis titled "Cytotoxicity studies of photocatalytically active titanium dioxide nanoparticles", he is currently working on his PhD thesis with the title "Development of zinc oxide based photocatalysts for the degradation of air pollutants". His research interests include semiconductor photocatalysis, nanotechnology and toxicological aspects of nanomaterials.

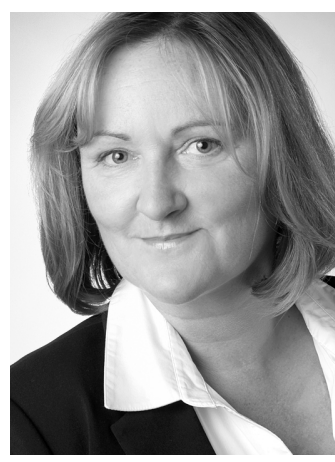

PD Dr. Cornelia Kasper is the head of the cell culture technology and tissue engineering group since the year 2000. In 2007 she successfully finished her habilitation in 2007 with the title: "New aspects in modern cell culture technology". Her research focus is the development of strategies for tissue engineering including the isolation, characterization, expansion and guided differentiation of stem cells from different sources. Furthermore, she has profound expertise in the cultivation of mammalian cell lines including common tumor cell lines for in vitro testing and cells for protein production. During the last few years she has also been involved in several projects with regard to drug and biomaterial testing including nanoparticles.

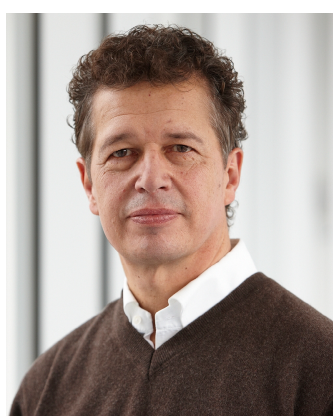

Detlef W. Bahnemann is Head of the Photocatalysis and Nanotechnology Research Unit at the Institute of Technical Chemistry of the Leibniz University Hannover since 2002. In the same year he was appointed as Honorary Professor of the Robert Gordon University in Aberdeen, United Kingdom. His research interests include-besides the entire field of photocatalysis-photoelectrochemical solar cells and fuel synthesis, fundamental aspects of semiconductor and metal nanoparticles, and membrane concepts for low temperature fuel cells. In close colaboration with industrial partners he also develops nanotechnological concepts for future product generations as well as appropriate analytical tools to determine their functionality. 